\title{
High tone in Moro: effects of prosodic categories and morphological domains
}

\author{
Peter Jenks • Sharon Rose
}

Received: 2 July 2009 / Accepted: 14 January 2011 / Published online: 11 March 2011

(C) The Author(s) 2011. This article is published with open access at Springerlink.com

\begin{abstract}
This paper presents a description and analysis of the tonal system of Moro, a Kordofanian language of Sudan, showing that the distribution of $\mathrm{H}$ (igh) tone is sensitive to a number of morphological and prosodic factors. First, we demonstrate that the distribution of $\mathrm{H}$ on nouns is sensitive to the OCP, both within roots and with affixes. Nouns also exhibit lexical distinctions between forms that exhibit unbounded rightward spreading of $\mathrm{H}$ and those that show no spreading. We model this distinction using cophonologies. While the distribution of $\mathrm{H}$ on Moro verb stems bears some
\end{abstract}

We are immensely grateful to our Moro speakers, Elyasir Julima and Ikhlas Elahmer, for sharing their language with us. We thank audiences at the $45^{\text {th }}$ Annual Meeting of the Chicago Linguistic Society, the Annual Conference on African Linguistics 37 and 40, the Massachusetts Institute of Technology, the University of Florida, the University of California, Santa Barbara and Harvard University for useful feedback and comments. We appreciate in-depth comments and discussion from Eric Baković, Larry Hyman, Victor Manfredi, Andrew Nevins, David Odden, and participants in the San Diego Phonology Interest Group and UCSD Phonetics Laboratory meetings. The members of the Moro Language Project, particularly Farrell Ackerman and George Gibbard, helped in numerous, immeasurable ways in both checking the data and refining the analysis. Finally, two anonymous reviewers and the associate editors, Michael Kenstowicz and Junko Itô, provided us with challenging comments and advice for improving the paper, for which we are grateful. Portions of Sect. 4 of this paper will appear with a slightly different analysis under the title 'Syllable weight and high tone in Moro' in Proceedings from the Annual Meeting of the Chicago Linguistic

Society 45. This material is based upon research supported by the National Science Foundation under Grant No. 0745973 'Moro Language Project'. Any opinions, findings and conclusions or recommendations expressed in this material are those of the authors and do not necessarily reflect the views of the National Science Foundation (NSF).

P. Jenks $(\bowtie)$

Department of Linguistics, Harvard University, 3rd Floor, Boylston Hall, Cambridge, MA 02138, USA

e-mail: pjenks@fas.harvard.edu

S. Rose

Department of Linguistics, University of California, San Diego, 9500 Gilman Drive \#108, La Jolla, CA 92093-0108, USA

e-mail: rose@ling.ucsd.edu 
similarities to nouns, crucial differences emerge. Rightward $\mathrm{H}$ tone spreading is binary on verbs, and sensitive to the weight of the syllable in terms of both the presence of an onset and a coda. We model this effect as $\mathrm{H}$ tone spreading within a binary foot. Furthermore, unlike nouns, underlying representations play little role in the distribution of $\mathrm{H}$ on verb roots. $\mathrm{H}$ tone is predictably distributed within a morphological category, the derived stem (D-stem), similar to a constituent recognized in Bantu languages (e.g. Downing 2000). Finally, we analyze competition between H associated with the $\mathrm{D}$-stem and $\mathrm{H}$ associated with affixes. This $\mathrm{H}$ tone competition is an OCPdriven effect occurring within the macrostem.

Keywords Tone $\cdot$ Prosody $\cdot$ Cophonology $\cdot$ Morphological domains $\cdot$ Tone doubling $\cdot \mathrm{OCP}$

\section{Introduction}

This paper describes and analyzes the main features of the tone system of the Thetogovela dialect of Moro, a Kordofanian language of the Western Heiban branch (Schadeberg 1981) spoken in the Nuba Mountains of central Sudan. The paper meets several objectives: One, we provide a basic description of the tone system of Moro, demonstrating that it is indeed a tone language and analyze the distribution of tone in both nominal and verbal categories; two, we show that the tone system exhibits lexical and morphological restrictions on high tone extension and high tone deletion; three, we show how the distribution of tone in the verb stem is similar to nouns, but is constrained by syllable size, the metrical foot and a morphological constituent, the derived stem; four, we show how the domain of tonal Obligatory Contour Principle (OCP) effects within verbs is confined to the macrostem, a morphological domain also found in Bantu languages; five, we show that there are lexical tone patterns that do not fit the general pattern, and we propose that these are produced from constraint rankings associated with lexical classes in a cophonology analysis.

Overall, the Moro data makes significant contributions to the typology of tone distribution, demonstrating multiple prosodic and morphological layers of restrictions on the position and extension of tone. From a theoretical point of view, the Optimality Theory (OT) analysis we present utilizes general constraints referencing prosodic and morphological structure, and utilizing input-output relationships only where they are crucial.

The structure of the paper is as follows. In Sect. 2, we give a brief overview of the sound system of Moro. In Sect. 3 we present the lexical and morphological distribution of tone in nouns, which is constrained by the OCP. This includes the introduction of high tone spreading, and evidence for lexical distinctions in tone spreading. In Sect. 4, we provide a description and analysis of verbal tone, focusing in particular on how the distribution of high tone is connected to syllable size and prosodic feet. We also motivate a morphological unit within the verb, the derived stem. In Sect. 5 
we present tone deletion patterns, arguing that they follow from the OCP applying within another, larger unit within the verb, the macrostem.

\section{Overview of sound systems}

Before presenting the Moro tone system, some basics of the segmental system will be provided. The vowel inventory of Moro is given in (1):

(1) Vowel inventory

$\begin{array}{llll}\mathrm{i} & & & \\ \mathrm{e} & \partial & \Lambda & \mathrm{u} \\ & & \mathrm{a} & \end{array}$

The vowel [ə] can be epenthetic or a reduced version of the peripheral vowels /i e o u/. It also appears in roots with no obvious source of reduction. Vowel harmony raises the vowels /a e o/ to [ $\Lambda \mathrm{i}$ u] respectively. Light diphthongs such as [iə], [eə], [oa] and $\left[\mathrm{u}_{\Lambda}\right]$ are also attested. Light diphthongs count as a single tone-bearing unit. We mark tone on the second vocalic portion of the diphthong. Vowel length is not contrastive, but lengthening is often observed in open penultimate or root-initial syllable.

Below is the consonant inventory of Moro:

(2) Consonant inventory

$\begin{array}{lllllll} & \text { LABIAL } & \text { DENTAL } & \text { ALVEOLAR } & \text { RETROFLEX } & \text { PALATAL } & \text { VELAR } \\ \text { STOP } & \mathrm{p} \mathrm{b} & \mathrm{td} & \mathrm{td} & & \mathrm{kg} & \\ \text { AFFRICATE } & & & & & \mathrm{j} & \mathrm{j} \\ \text { FRICATIVE } & \mathrm{f} \mathrm{v} & \text { d } & \mathrm{s} & \mathrm{n} & \\ \text { NASAL } & \mathrm{m} & & \mathrm{n} & \mathrm{r} & \\ \text { TRILL } & & & \mathrm{r} & \mathrm{r} & & \\ \text { FLAP } & & & \mathrm{r} & & \mathrm{j} & \\ \text { LATERAL } & & \mathrm{w} & & & \end{array}$

Consonants can be geminated, with the exception of $[r, \mathrm{r}, \mathrm{j}]$. Voiced stops and $/ \mathrm{v} /$ are realized as voiceless when geminate.

\section{Lexical tonology of nouns}

In this section we outline the basic lexical tone melodies found on Moro nouns, and give a formal analysis of tone distribution. The tone patterns of nominals were ascertained from a corpus of approximately 300 nominal forms elicited primarily from one consultant, with additional contributions from a second. ${ }^{1}$ While they are not abun-

\footnotetext{
${ }^{1}$ Elicitation of word forms was conducted in two manners, by direct elicitation and through collection of sentences. Words reported in this paper were recorded both in isolation, in carrier sentences and in sentences in different positions. Transcriptions have been double-checked by two researchers.
} 
dant, minimal pairs such as those in (3) demonstrate the contrastive role of tone in Moro:

\begin{tabular}{llllll}
\multicolumn{2}{l}{ Tonal minimal pairs } \\
eðá & LH & 'why?' & eða & LL & 'meat' \\
wárá & HH & 'chicken' & wará & LH & 'tree' \\
ggárá & LHH & 'salt' & Đgará & LLH & 'hibiscus juice' \\
áveja & HLL & 'spring' & aveja & LLL & 'liver' \\
yálóná & HHH & 'kingdom' & jaləà & LLL & 'song'
\end{tabular}

The words in (3) show that there are two constrastive tone levels in Moro, which we refer to as $\mathrm{H}$ (igh) and $\mathrm{L}(\mathrm{ow})$, with only high tone indicated in transcription. Our data contain no lexical contour tones, but Moro does exhibit final lowering, in which final high tones are realized as falling tones phrase finally. ${ }^{2}$ Final lowering also causes final low tone to be realized as lower than preceding low tones. Nouns elicited in isolation also exhibit this effect. For example, a word such as ggárá 'salt' is pronounced [ngárâ] in isolation or in final position in a sentence such as kuku kanató

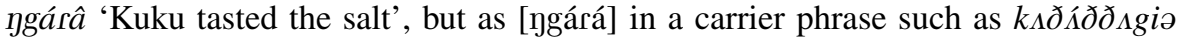
ygárá aten aten 'He is repeating "salt" slowly' or a sentence such as ggárá yitfí 'Salt is bad' whether the following word begins with high or low tone. Furthermore, when suffixes are added to words that end in high tone, no contour appears: ygárá-yá 'with the salt'. Because there are no contrasts between falling tone and high or low tone in other contexts, we conclude that falling tones are not lexical, but can be attributed to the contextual phonetic realization of high tone. In this paper, we only provide tone patterns without final lowering.

\subsection{Main lexical patterns}

All nouns are marked for noun class with a prefix, normally a single consonant, although vocalic prefixes do occur, and some vowel-initial nouns lack a prefix. There are eight main noun class pairings (singular/plural) and five major single noun classes, as illustrated in the following chart taken from Gibbard et al. (2009):

\footnotetext{
${ }^{2}$ If the final syllable is closed by a slight glottal stop, a final $\mathrm{H}$ tone does not fall.
} 
(4) Moro noun classes

\begin{tabular}{|c|c|c|c|c|c|c|c|}
\hline Class & $\begin{array}{l}\text { Initial } \\
\text { segment }\end{array}$ & $\begin{array}{l}\text { Concord } \\
\text { segment }\end{array}$ & Singular & $\begin{array}{l}\text { Initial } \\
\text { segment }\end{array}$ & $\begin{array}{l}\text { Concord } \\
\text { segment }\end{array}$ & Plural & Gloss \\
\hline $\mathrm{g} / \mathrm{l}$ & V- & g-/k- & evaja & $1-$ & $1-$ & ləvaja & 'poor person' \\
\hline $\mathrm{g} / \mathrm{n}$ & V- & $\mathrm{g}-/ \mathrm{k}-$ & otfta & n- & n- & nətfta & 'milk pot' \\
\hline $\mathrm{j} / \mathrm{j}$ & low V- & $\mathrm{j}-, \mathrm{k}-, \mathrm{s}-$ & ajén & high V- & j-, s- & ején & 'mountain' \\
\hline $1 / n$ & $1-/[-$ & $1-$ & ləbú & y- & $y-$ & yəbú & 'well' \\
\hline $1 / \mathrm{n}$ & $1-/[-$ & $1-$ & laywata & $\mathrm{n}-$ & $\mathrm{n}-$ & jaywata & 'water cup' \\
\hline ð/r & д- & ð- & ðaba & $\mathrm{r}-$ & $\mathrm{r}-$ & raba & 'cloud' \\
\hline ð/j & ð- & д- & ðamala & j- & $\mathrm{j}-, \mathrm{s}-$ & jamala & 'camel' \\
\hline $\mathrm{y} / \mathrm{n}$ & y- & $\mathrm{y}-$ & jusí & $\mathrm{n}-$ & $\mathrm{n}-$ & jusí & 'chick' \\
\hline $\mathrm{g}$ & V- & g-/k- & áyálá & $*$ & $*$ & $*$ & 'haze' \\
\hline j & V-/s- & $\mathrm{j}-, \mathrm{k}-, \mathrm{s}-$ & aveja & $*$ & $*$ & $*$ & 'liver' \\
\hline y & $\mathrm{y}-$ & y- & yágá & $*$ & $*$ & $*$ & 'sap' \\
\hline д & $\begin{array}{l}\text { b-/p-, } \\
\text { m-, д- }\end{array}$ & д- & ðəbárá & $*$ & $*$ & $*$ & 'cotton' \\
\hline ð & д- & ð- & ðávóléđáy & $*$ & $*$ & $*$ & 'pulling' \\
\hline
\end{tabular}

Tone is assigned to the whole noun, including the class prefix. This conclusion is supported by the behavior of nouns with vocalic prefixes, which may have high or low tone (class $\mathrm{j} / \mathrm{j}$ : á-wáná 'sugar cane' vs. a-yora 'elephant'). Tone on the prefix does not have to match that of the root (class $\mathrm{j} / \mathrm{j}$ : a-jén 'mountain'), but we have found no cases of high tone on the prefix combined with a following low tone on the root. A HL nominal pattern is scarce whether the $\mathrm{H}$ falls on a noun class prefix or on the first vowel of the root.

Monosyllabic nouns are rare. The few examples that occur have high tone: ex. gí 'farm' and $\partial i$ 'thorn'. Nouns with two tone-bearing units (TBU) are frequent (45\% of our database) and all four possible combinations of high and low tone are attested on them. Noun class prefixes (either vowels or nasals) may count as one of the two TBUs, although nasals in other positions are usually non-tone bearing.

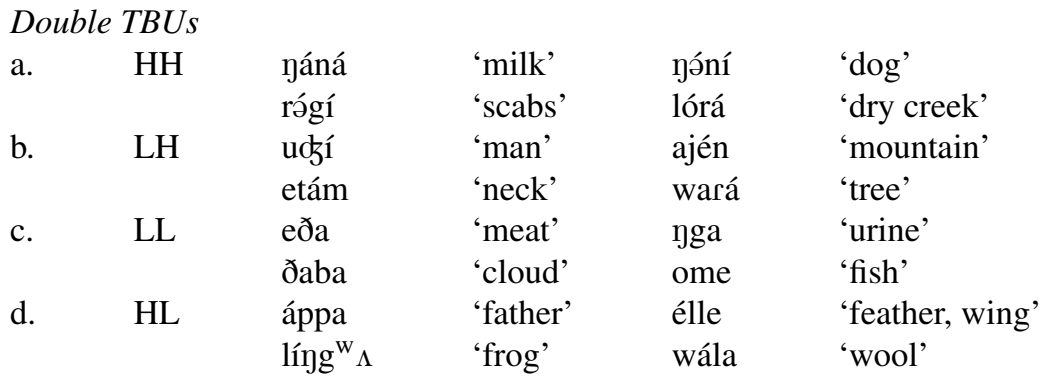

The HL pattern is rarer than the other three patterns, occurring in only eight words in our data compared to $53 \mathrm{HH}, 35 \mathrm{LL}$ and $34 \mathrm{LH}$. Six of the eight HL forms have an initial heavy syllable: a medial geminate, or nasal-consonant cluster. Thus, heavy syllables appear to attract $\mathrm{H}$ tone if $\mathrm{H}$ tone is present. Nevertheless, heavy syllables 
do not always condition a HL pattern: ex. ðáppá 'friend' (HH) and ðoppa 'star' (LL), and there is one HL word with no initial heavy syllable: ádiə 'cooking pot'.

Words with three TBUs represent $42 \%$ of our database. There are four main patterns, given below (6a-d) with numerous examples of each type (41 HHH, 26 LLL, $25 \mathrm{LLH}, 17 \mathrm{LHH})$. In addition, there are some less common forms (6e-g) with fewer attestations (11 LHL, 2 HHL, 2 HLL):

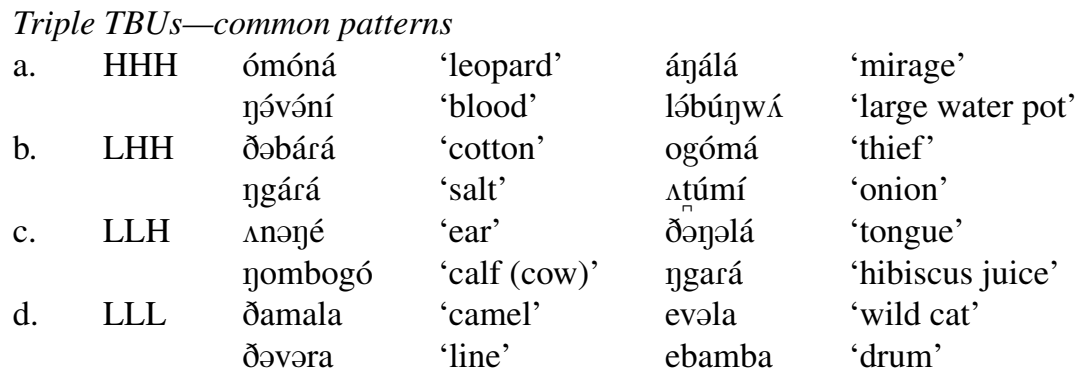

Triple TBUs-less common patterns

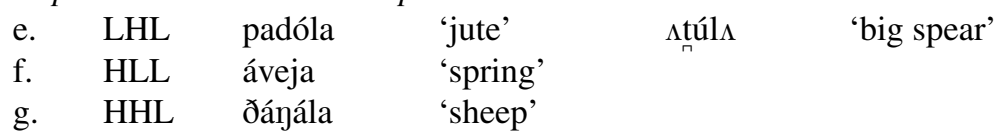

There are approximately 30 words with four TBUs in our database, representing $10 \%$ of the corpus. The three most frequent patterns are LLLL (6), HHHH (5) and LLHH (10). The other categories range from 1 to 3 examples, and there are observable borrowings from Arabic (ex. alongréma 'bed' $<$ Sangarajb 'traditional wooden-framed rope bed', slbúmbəriə < bambar 'stool' or even lə̄gńlləme > gal' $^{\text {Sam }}$ 'pen'). ${ }^{3}$

Quadruple TBUs

\begin{tabular}{|c|c|c|c|c|c|}
\hline \multirow[t]{2}{*}{ a. } & LLLL & nabəg ${ }^{\mathrm{W}}$ ala & 'papers' & odərəgala & 'turtle' \\
\hline & & iməgəniə & 'excrement' & ðəbarəla & 'river bed' \\
\hline \multirow[t]{2}{*}{ b. } & НННН & yóðámáná & 'beans' & ómótfáđá & 'afterbirth' \\
\hline & & yártómáđá & 'tiny lizard' & úmíđว́ní & 'pocket, silo' \\
\hline \multirow[t]{2}{*}{ c. } & LLHH & ogovélá & 'monkey' & omªróyá & 'Moro person' \\
\hline & & idəvíní & 'shoe' & logopájá & 'cup' \\
\hline d. & LHHH & evártónjé & 'type of tree' & $\Lambda$ tóḿn $r^{\mathrm{w}} \hat{\Lambda}^{4}$ & 'date' \\
\hline e. & LLLH & ndapəogá & 'nail' & & \\
\hline f. & LLHL & aləngréma & 'bed' & bəlúkriə & 'dove' \\
\hline $\mathrm{g}$ & LHLL & $\Lambda$ lb ́́mbəriə & 'stool' & ləђgর́lləme & 'pen' \\
\hline $\mathrm{h}$ & LHHL & atfóng ª́ra & 'bird of prey' & & \\
\hline i. & HHHL & Ártónótiə & 'armpit' & & \\
\hline
\end{tabular}

\footnotetext{
${ }^{3}$ Arabic words are taken from James Dickins's Arabic/English Dictionary of Sudanese Arabic.

${ }^{4}$ This word is one of the rare cases where nasal bears high tone.
} 
The tone patterns are summarized below with all possible combinations of $\mathrm{H}$ and $\mathrm{L}$ provided. Shading indicates common patterns and unshaded forms indicate the less common forms. Strikethroughs are unattested patterns in our sample.

Summary of nominal lexical tone patterns

\begin{tabular}{|l|l|l|l|l|l|l|l|l|}
\hline Binary & LL & HH & LH & HL & \multicolumn{4}{|l|}{$\mid$} \\
\hline Triple & LLL & HHH & LLH & LHH & HLL & HHL & LHL & HLH \\
\hline Quadruple & LLLL & HHHH & LLLH & LLHH & HLLL & HHLL & LHLH & HLHL \\
\hline & LLHL & HHLH & LHLL & LHHH & HLHH & HHHL & LHHL & HLLH \\
\hline
\end{tabular}

There are two key generalizations for the tone patterns. First, no word contains more than one $\mathrm{H}$ tone separated by a L tone, e.g. *HLH or *HHLH, but the opposite LHL or LLHL sequence is found. Second, the less common patterns among the double and triple TBU nouns are those that have a $\mathrm{L}$ tone at the right edge. We now examine the interaction of these lexical patterns with two affixes in Moro, both of which condition rightward high tone extension.

\section{2 $\mathrm{H}$ tone processes with nominal affixes}

Two affixes in nominal forms interact with the tone of the root, the instrumental/comitative suffix /-Ca/ and a locative prefix /é-/ indicating 'location inside' 5 The instrumental/comitative suffix consists of a concord consonant indicating noun class, and the vowel /a/. The tone matches the tone of the final syllable of the noun. We give only roots with two or three tone-bearing units, but the pattern is the same for longer nouns.

\section{Instrumental / $-\mathrm{Ca} /$}

$\begin{array}{lllllll} & \text { Final H } & \text { Instrumental } & & \text { Final L } & \text { Instrumental } & \\ \text { a. } & \text { LH-H } & \text { uóí-gá } & \text { 'man' } & \text { LL-L } & \text { eða-ga } & \text { 'meat' } \\ \text { b. } & \text { HH-H } & \text { yə́ní-yá } & \text { 'dog' } & \text { HL-L } & \text { áppa-ga } & \text { 'father' } \\ \text { c. } & \text { LLH-H } & \text { ðəjəlá-ðá } & \text { 'tongue' } & \text { LLL-L } & \text { ðamala-ða } & \text { 'camel' } \\ \text { d. } & \text { LHH-H } & \text { ðəbárá-ðá } & \text { 'cotton' } & \text { HLL-L } & \text { áveja-ga } & \text { 'spring' } \\ \text { e. } & \text { HHH-H } & \text { yə́vóní-yá } & \text { 'blood' } & \text { LHL-L } & \text { padóla-ða } & \text { 'jute' }\end{array}$

The instrumental suffix acquires $\mathrm{H}$ tone from the final syllable of the noun; otherwise it is low.

The locative 'inside' prefix is /é-/. Before noun roots which condition high vowel harmony, it is realized as [í] ([ə] is transparent to harmony). When attached to a vowel-initial root, the prefix is followed by $[\mathrm{k}]$ or $[\mathrm{s}] .{ }^{6}$ The high tone of the prefix spreads rightward onto the noun root. $\mathrm{H}$ tone spreads to the right word edge (10a)

\footnotetext{
${ }^{5}$ Moro has two locative 'inside' affixes: /é-/ generally used for location within an uncovered enclosure and I-ánó/ generally used for location inside a concealed or covered space.

${ }^{6}$ The choice is determined by noun class (Gibbard et al. 2009). If there is a voiceless obstruent in the following syllable, $[\mathrm{g}]$ occurs instead of [k], a type of voicing dissimilation.
} 
unless there is another $\mathrm{H}$ tone, in which case spreading halts one TBU away from the $\mathrm{H}$ tone. ${ }^{7}$ In (10b), no spreading occurs because the words begin with a $\mathrm{H}$ tone. In (10c), the $\mathrm{H}$ tone is on the second TBU, so no spreading takes place. ${ }^{8}$

\section{Locative /é-/}

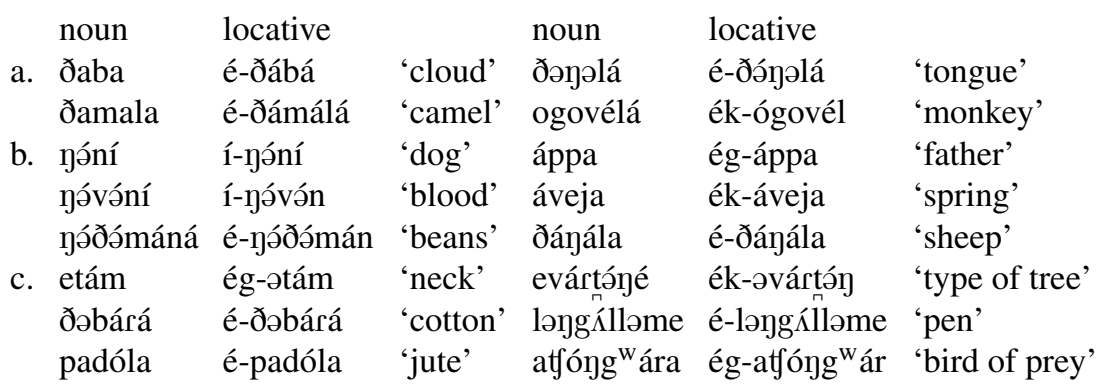

These are the only nominal affixes that interact with the tone of the root. Other low-toned affixes do not acquire high tone via spreading. This includes the objective case marker /-o/, found on consonant-final proper nouns: ex. [bitər-o] 'Peter-OBJ.', and the locative enclitic nano. The objective case marker is optional, and nano can be separated from the noun, so their non-participation is not surprising. There are suffixes with high tone, but they do not interact with the tone of the noun roots. An example is locative /-ánó/. The suffix vowel causes deletion or gliding of the final root vowel, but no tonal change.

\section{Locative /-ánó/}

\begin{tabular}{|c|c|c|c|c|c|c|c|}
\hline & & locative & & & noun & loc & \\
\hline & & ed & & d & & & T' \\
\hline $\mathrm{L}$ & veja & ávejánó & spring' & LHLL & lə⿹gর́lləme & lə⿹gর́lləmjánó & pen' \\
\hline
\end{tabular}

To summarize, the affixes illustrate a pattern of rightward high tone spreading either from prefix to root or from root to suffix. No pattern of leftward high tone spreading is observed, and separate high tones on both affixes and noun stems are attested.

\subsection{Analysis of noun patterns}

We begin with an OT analysis of the four common triple TBU patterns, LLL, LLH, $\mathrm{LHH}$ and $\mathrm{HHH}$. We assume that low tone is unmarked in Moro, as is the case in many Bantu languages. The coexistence of specified $\mathrm{H}$ and $\mathrm{L}$ tones tends to coincide with the presence of contour tones (Hyman 2001). Contour tones do not occur in Moro, except as a phonetic implementation of final $\mathrm{H}$ in phrase-final position. Moreover,

\footnotetext{
${ }^{7}$ Another alternative tone pattern found with this prefix involves spreading only one TBU rightwards, e.g. éðámala 'in the camel'.

${ }^{8}$ The locative form occasionally shows apocope of the final vowel in longer words.
} 
if $\mathrm{L}$ is specified, one expects to see processes or constraints that refer specifically to L. Yet, there are no clear cases of L spreading, and no constraints, such as the OCP, referencing L. Sequences such as HLH are unattested, but LHL is possible. We therefore make the uncontroversial assumption that all low-toned nouns in Moro lack an input specification for $\mathrm{H}$ tone. Such nouns could, of course, be subject to a highranked constraint against high tone specific to these nouns, but Lexicon Optimization (Prince and Smolensky 1993) dictates the more straightforward assumption that input and output are as faithful as possible unless there is evidence to the contrary. LLL forms, as well as LL and LLLL, are assumed to derive from inputs that lack high tones.

The other three patterns, HHH, LHH and LLH, can be accounted for by adopting the position that an underlying high tone is associated to the initial, medial or final TBU respectively and extended to the right word edge:

(12) Underlying and surface representations of trisyllabic nouns with common tone patterns

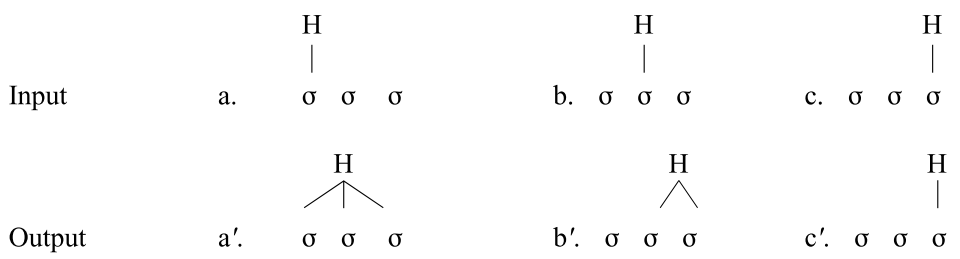

Rightward $\mathrm{H}$ tone extension in Moro is independently observed in the behavior of the prefixes outlined in (9-10). We first present an analysis assuming the inputs in (12), and then consider some alternate inputs for the same outputs.

Some basic constraints are necessary to generate the patterns: an alignment constraint to produce tone spreading, and constraints to regulate the input-output mapping, disfavoring deletion, insertion, spreading, or shifting of tone. Although the faithfulness constraints MAX/DEP can be applied to tone (Myers 1997), reference to faithful maintenance of association lines is required to penalize spreading or shifting. An alternate approach is to use Ident constraints, which regulate both the presence and position of the output tone (Bickmore 1999; de Lacy 2001). We follow Bickmore (1999) in using IDENT-IO(H) to regulate tone deletion or tone shifting, and the markedness constraint $* \mathrm{H}$ to penalize spreading. This constraint is violated by any surface high tone, whether a multiply-linked autosegment $\mathrm{H}$ or not.
$\operatorname{Align}(\mathrm{H}, \mathrm{R} ; \mathrm{WD}, \mathrm{R})$
Align right edge of $\mathrm{H}$ with right edge of word.
IDENT-IO(H)
*H
If mora $x$ bears $\mathrm{H}$ tone in the input, then the output correspondent of $x$ bears $\mathrm{H}$ tone.
A mora cannot be H-toned.

$\operatorname{AligN}(\mathrm{H}, \mathrm{R})$ outranks the constraint $* \mathrm{H}$, which prevents spreading, as shown for ómóná 'leopard'. We assume that skipping an intervening TBU is prevented by highranked NoGAP. 
(14) Ranking producing spreading in nouns: $\operatorname{AligN}(\mathrm{H}, \mathrm{R}) \gg * \mathrm{H}$

\begin{tabular}{|c|c|c|}
\hline /ómona/ & Align(H,R) & ${ }^{*} \mathrm{H}$ \\
\hline \hline a. ómona & $* ! *$ & ${ }^{*}$ \\
\hline b. ómóna & $* !$ & ${ }^{* *}$ \\
\hline$\sigma$ c. ómóná & & $* *$ \\
\hline
\end{tabular}

Other means of satisfying $\operatorname{ALIGN}(\mathrm{H}, \mathrm{R})$ would be to shift $\mathrm{H}$ tone to the final position (15c) or to delete it (15d). These options are ruled out by IDENT-IO(H), which is also ranked above $*$ H. IDENT-IO $(H)$ penalizes a mismatch between the input vowel that bears $\mathrm{H}$ tone and its output.

(15) Ranking preventing shifting in nouns: $\mathrm{IDENT}-\mathrm{IO}(\mathrm{H}) \gg * \mathrm{H}$

\begin{tabular}{|c||c|c|c|}
\hline /ómona/ & Ident-IO(H) & $\operatorname{Align}(\mathrm{H}, \mathrm{R})$ & ${ }^{*} \mathrm{H}$ \\
\hline \hline a. ómona & & $* ! *$ & $*$ \\
\hline$\sigma$ b. ómóná & & & $* * *$ \\
\hline c. omoná & $* !$ & & $*$ \\
\hline d. omona & $* !$ & & \\
\hline
\end{tabular}

The other two common outputs in Moro nouns, LHH and LLH, are generated using the same assumptions, with $\operatorname{ALIGN}(\mathrm{H}, \mathrm{R})$ requiring rightward spreading.

Inputs with multiply-linked tones must also be considered. The following inputs would still give rise to $\mathrm{HHH}$ and $\mathrm{LHH}$ given the ranking proposed:

(16) Alternative underlying representations for trisyllabic nouns
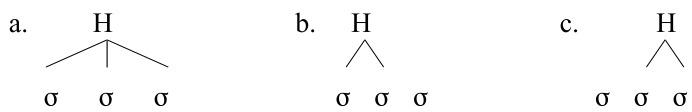

The first input (16a) is bound by faithfulness to surface as HHH. The second, (16b), will undergo spreading to the third TBU due to $\operatorname{ALIGN}(\mathrm{H}, \mathrm{R})$, and surface as $\mathrm{HHH}$, too. The third, $(16 \mathrm{c})$, satisfies $\operatorname{ALIGN}(\mathrm{H}, \mathrm{R})$. The output LHH results as there is no leftward alignment constraint ranked above faithfulness to induce leftward spreading. This exhausts the possibility of inputs with a single $\mathrm{H}$ tone autosegment. Given these three constraints, any input with a single $\mathrm{H}$ tone produces one of the attested outputs HHH, LHH or LLH.

The less common triple TBU tone patterns in Moro (HLL, LHL, HHL) do not follow from the current ranking. These cases do not show $\mathrm{H}$ tone extension to the right edge, and some show no tone spreading at all. Let us consider first the cases of no tone spreading, HLL and LHL, which each exhibit a single fixed high tone. In order to generate these patterns, we propose that the ranking between the markedness constraint $* \mathrm{H}$ and the spreading constraint $\operatorname{ALIGN}(\mathrm{H}, \mathrm{R})$ is reversed, as shown in (17), but IDENT-IO(H) still outranks $* \mathrm{H}$. This ranking produces an output with a single $\mathrm{H}$ tone. 
(17) Ranking for nouns without spreading: ${ }^{*} \mathrm{H} \gg \operatorname{ALIGN}(\mathrm{H}, \mathrm{R})$

\begin{tabular}{|c|c|c|c|}
\hline \multicolumn{1}{|c|}{ /áveja/ } & Ident-IO(H) & ${ }^{*} \mathrm{H}$ & Align(H,R) \\
\hline \hline a. ávéjá & & $* * * !$ & \\
\hline b. ávéja & & $* * !$ & $*$ \\
\hline$\infty$ c. áveja & & $*$ & $* *$ \\
\hline d. aveja & $* !$ & & \\
\hline
\end{tabular}

The same analysis would hold for LHL assuming that the $\mathrm{H}$ tone is associated to the medial TBU in the input. If multiply-linked $\mathrm{H}$ tones constitute possible inputs as previously discussed, then the other pattern HHL could result from a multiply-linked input $/ \mathrm{H}_{\mathrm{i}} \mathrm{H}_{\mathrm{i}} \mathrm{L}$, where subscripts indicate multiple linking of a single $\mathrm{H}$ autosegment.

We are therefore dealing with at least two lexical classes, a rightward spreading class and a faithful no-spreading class. The distinction between these classes is not reducible to an independent grammatical factor, and so we conclude that it must be located in the lexicon. Such a distinction can be modeled using cophonologies in OT, constraint rankings that are associated with particular classes of words or morphological constructions in the lexicon (Anttila 2002, 2009; Anttila and Bodomo 2007; Inkelas 1999; Inkelas and Zoll 2007; Orgun 1996; and others). General constraints rank differently to produce the two patterns. The common patterns HHH, LHH, LLH are produced with the $\operatorname{ALIGN}(\mathrm{H}, \mathrm{R}) \gg{ }^{*} \mathrm{H}$ ranking (15), whereas the pattern $* \mathrm{H} \gg$ $\operatorname{ALIGN}(\mathrm{H}, \mathrm{R})$ generates LHL, HLL and HHL (17).

No Moro noun contains more than one $\mathrm{H}$ tone separated by one or more TBUs with L tone: e.g. *HLH, *HLLH. We attribute this to the OCP (Leben 1973; Goldsmith 1976; Myers 1997), which prevents an input with two separate underlying $\mathrm{H}$ tones from surfacing:

(18) OCP-H A phonological domain may not contain two $\mathrm{H}$ autosegmental tones.

The OCP typically pertains to adjacent underlying tones or tonal domains, that is, identical but disjoint tones realized on adjacent TBUs (Myers 1997; Odden 1986, 1994). Sequences of surface high tones in Moro nouns do not violate (18) because they are linked to the same underlying H. However the OCP can still be in effect at a distance (Alderete and Frisch 2007; Odden 1994; Suzuki 1998), applying between adjacent segments, syllables, or at greater distances.

The constraint in (18) penalizes adjacent separate $\mathrm{H}$ tones as well as those separated by toneless $\mathrm{TBU}(\mathrm{s})$. In input forms with two separate autosegmental $\mathrm{H}$ tones, which must arise due to Richness of the Base (Prince and Smolensky 1993), highranked OCP-H forces modification of the output. There are two possible modifications: deletion of one of the input tones or fusion of the two tones. If a tone is deleted, it incurs a violation of IDENT-IO(H); if tones are fused, UNIFORMITY (McCarthy and Prince 1995), which penalizes multiple correspondence between output and input, is violated. We provide a tableau showing fusion on the winning candidate, illustrated in (19). Candidate (19d) contains a single $\mathrm{H}$ tone that corresponds to both input $\mathrm{H}$ tones, while (19a) contains two autosegmental $\mathrm{H}$ tones, violating OCP-H. 
(19) Ranking resolving inputs with multiple $H$ : OCP-H, IDENT-IO(H) $\gg U$ UNIFORMITY

\begin{tabular}{|c||c|c|c|c|c|}
\hline /ómoná/ & OCP-H & IDENT-IO(H) & ALIGN(H,R) & UNIFORMITY & $*$ H \\
\hline \hline a. ómoná & $* !$ & & $* *$ & & $* *$ \\
\hline b. omoná & & $* !$ & & & $*$ \\
\hline c. ómona & & $* !$ & $* *$ & & $*$ \\
\hline$\sigma$ d. ómóná & & & & $*$ & $* *$ \\
\hline
\end{tabular}

If UNIFORMITY outranked OCP-H or IDENT-IO(H), on the other hand, candidate (19b) would win. It is worth noting that all of the outputs that do not violate OCP-H are attested tone patterns. In (19), the two separate $\mathrm{H}$ tones are separated in the input, but adjacent discrete $\mathrm{H}$ tones in a form such as $\mathrm{LH}_{\mathrm{i}} \mathrm{H}_{\mathrm{j}}$ would also produce one of the common patterns: $\mathrm{LLH}_{\mathrm{j}}$ (deletion) or $\mathrm{LH}_{\mathrm{i}} \mathrm{H}_{\mathrm{i}}$, where the subscripts indicate multiple linking of a single $\mathrm{H}$ autosegment (fusion). We stipulate the ranking in (19) for now; evidence in favor of this ranking is provided in Sect. 3.4. In summary, the following ranking is proposed for the trisyllabic forms: OCP-H, IDENT-IO(H) $\gg$ UNIFOR$\operatorname{MiTY}, \operatorname{AligN}(H, R) \gg * H$, with a reverse ranking of $* \mathrm{H} \gg \operatorname{Align}(H, R)$ for the less common non-spreading patterns.

This analysis extends to double and quadruple TBU patterns. For double patterns, $\mathrm{HH}$ follows from the spreading ranking, whereas LL and LH are produced with either ranking. The rarer $\mathrm{HL}$ arises from the ranking $* \mathrm{H} \gg \operatorname{ALIGN}(\mathrm{H}, \mathrm{R})$. As for quadruple patterns, the unattested forms with more than one autosegmental $\mathrm{H}$ tone *HHLH, *HLHH, *HLLH are all ruled out by OCP-H. Forms that end in a $\mathrm{H}$ tone $(\mathrm{HHHH}$, LLHH, LHHH, LLLH) are generated by the ranking $\operatorname{AligN}(\mathrm{H}, \mathrm{R}) \gg * \mathrm{H}$, as was the case for the triple TBU forms. HHHH is generated by assuming at least an underlying $\mathrm{H}$ associated to the initial TBU (/HLLL/). LLHH and LHHH are produced by $\operatorname{AligN}(H, R)$ forcing $H$ tone extension to the right edge of the word from inputs where the first $\mathrm{H}$ is associated to the penultimate (/LLHL/) or antepenultimate (/LHLL/) TBU respectively. LLLH follows the pattern of LLH, and can surface from faithful /LLLH/ or from an OCP-violating form /HLLH/ or /LHLH/ if deletion is the favored ranking. This accounts for the quadruple forms that end in a $\mathrm{H}$ tone. The remaining patterns with a final low are LLHL, LHHL, HHHL, LHLL. These all arise from outputs that are faithful to their inputs due to the ranking $* H \gg \operatorname{Align}(H, R)$. This analysis also predicts *HHLL and *HLLL, which are unattested. However, as four syllable forms are rare, we assume that these are accidental gaps.

It is also possible that a third lexical class exists, which disfavors $\mathrm{H}$ tone on the final syllable. A constraint NON-FINALITY, which prevents spreading to the final TBU, would be ranked above $\operatorname{Align}(H, R)$ (Cassimjee and Kisseberth 1998). HHL could surface from the input $/ \mathrm{HLL} / \mathrm{in}$ addition to $/ \mathrm{H}_{\mathrm{i}} \mathrm{H}_{\mathrm{i}} \mathrm{L} /$. The outputs LHHL and HHHL could result from /LHLL/ and /HLLL/ respectively. Finally, the form /LLHL/ will not undergo spreading under this ranking. As there are only a few forms that would be produced from this additional ranking via spreading rather than multiple input tones, it is not clear if there is an advantage to be gained from positing an additional lexical class. However, we will see further evidence that NON-FINALITY is active in Moro from the verbal patterns in Sect. 4. 
The lexical patterns which define $\mathrm{H}$ melodies on Moro nouns are commonly attested in other African languages. Rightward H spreading is a typical Bantu pattern (Bickmore 1999; Cassimjee and Kisseberth 1998; Kisseberth and Odden 2003). The 'no spreading' pattern is found in other Bantu languages such as Runyambo (Bickmore 1989), RuHaya (Hyman and Byarushengo 1984) and Ruciga (Cassimjee and Kisseberth 1998; Kisseberth and Ndabarasa 1993), whose nouns have a single H tone and no spreading. A non-final pattern, if adopted, is a common pattern in Bantu verb stems (Kisseberth and Odden 2003), and is found in nouns in the Cushitic language Ts'amakko (Savà 2005) in which nouns end in L normally preceded by a H tone. These cross-linguistic patterns support the generality of the constraints and their rankings. ${ }^{9}$

To summarize, there are at least two lexical classes in the nouns, corresponding to two cophonologies of ranked constraints, shown in italics. The ambiguous cases span both classes:

(20) Summary of constraint rankings for nouns

\begin{tabular}{|c|c|}
\hline H Spread & No Spread \\
\hline Align(H,R) IdENT-IO(H) & IDENT-IO(H) \\
& * \\
\hline HH, HHH, LHH & ALIGN(H,R) \\
\hline HHHH, LHHH, LLHH & HL, LHL, HHL, HLL \\
\hline \multicolumn{2}{|c|}{ LH, LLH, LLLH } \\
\hline
\end{tabular}

\subsection{Spreading in affixes}

We now turn to the spreading patterns of the nominal affixes. Recall from Sect. 3.2 that high tone may spread from the last TBU of a noun root to a suffix, ex. Đóvóní-gá 'with blood' vs. padóla-ða 'with jute' *padólá-ðá. This pattern illustrates that the domain of tonal spreading is the word. Those forms which have a final $\mathrm{H}$ tone are generated by high tone spreading to the affix, a result of $\operatorname{AligN}(\mathrm{H}, \mathrm{R}) .{ }^{10}$ However, if the last TBU does not bear high tone in the unaffixed form, high tone does not extend rightwards to the suffix. We previously established that words of this type have the ranking $* \mathrm{H} \gg \operatorname{ALIGN}(\mathrm{H}, \mathrm{R})$ for root-internal tone distribution. This ranking is also responsible for blocking spreading to the affix.

The case of spreading from a high-toned prefix onto the noun stem is more complex. In these cases, $\mathrm{H}$ tone spreads from the prefix until another $\mathrm{H}$ tone is encoun-

\footnotetext{
${ }^{9}$ Another analysis of lexical classes would be with lexically indexed constraints (e.g. Fukazawa 1999; Itô and Mester 1994, 1999; Pater 2007, 2009). The two approaches are similar, but the cophonologies analysis lines up well with typological data from other tone languages. In line with Anttila (2009), we adopt the idea that constraints may be indexed for general morphological domains such as root or stem, but eschew lexically-indexed rankings.

${ }^{10}$ The fact that noun roots with final $\mathrm{H}$ consistently show $\mathrm{H}$ tone spread to the affix indicates that the correct analysis of these forms is with the spreading ranking rather than the faithful no-spreading ranking.
} 
tered, but stops one syllable away, ex. /é-ðəyəlá/ $\rightarrow$ é-ðð́yəlá 'in a tongue'. The blocking of spreading by a $\mathrm{H}$ root tone is analyzed as a local OCP effect, a blocking process attested in other languages such as Setswana (Mmusi 1992) and Shona (Myers 1987, 1997). This effect is different from the simple OCP-H which bans lexical *HLH or *HLLH sequences, no matter the distance between the two H. In this case, adjacency is a factor. To account for this distinction we propose, following Suzuki (1998), to split the OCP into a local and an unbounded version:

\section{$\mathrm{OCP}-\mathrm{H}(\mu)$ $\mathrm{OCP}-\mathrm{H}$}

A domain may not contain two $\mathrm{H}$ tones on adjacent moras A domain may not contain two $\mathrm{H}$ tones

The lexical tone patterns exclude HLH, which was previously attributed to OCP-H outranking both IDENT-IO(H) and UNIFORMITY. Yet such a pattern is tolerated if the initial $\mathrm{H}$ is associated with an independent prefix: é-gotám 'in the neck'. Neither deletion of a tone nor fusion $(/ \mathrm{H}-\mathrm{LH} / \rightarrow \mathrm{HHH})$ is possible. Assuming that the same ranking holds with longer words, this can be attributed to a morphological disjointness constraint (Struijke 2002, p. 34) which prevents two H tones from fusing if they originate on different morphemes:

\section{MORPH-DISJOINT}

Let $\mathrm{x} \in$ morpheme $\mathrm{X}$ in the input and $\mathrm{y} \in$ morpheme $\mathrm{Y}$ in the input, $\mathrm{x}$ and $\mathrm{y}$ tones, then there is some correspondent of $\mathrm{x}$ in the output that cannot equal the correspondent of $\mathrm{y}$.

This constraint prevents fusion across morpheme boundaries, and high-ranked IDENT-IO(H) prevents tone deletion. OCP-H $(\mu)$ outranks $\operatorname{AligN}(H, R)$, forcing tone spreading to stop one TBU away from another $\mathrm{H}$ tone. Tone domains are indicated with brackets:

(23) Restricted spreading from lé-/ prefix: MORPH-Dis, IDENT-IO(H) 》 OCP$\mathrm{H}(\mu)$, OCP-H

\begin{tabular}{|c|c|c|c|c|c|}
\hline /é-ogovéla/ & MORPH-DIS & IDENT-IO(H) & OCP-H( $(\mu)$ & OCP-H & $\mathrm{AL}(\mathrm{H}, \mathrm{R})$ \\
\hline \begin{tabular}{|c|}
$\mathrm{H}_{1}$ \\
a. [é]k-ogo[vé
\end{tabular} & & & & $*$ & $* * * !$ \\
\hline$\bigwedge_{\text {b. [ék-ó]go[vél] }}^{\mathrm{H}_{1}}$ & & & & $*$ & $* *$ \\
\hline c. [ék-ógó][vél] & & & $* !$ & $*$ & $*$ \\
\hline $\begin{array}{r}\mathrm{H}_{2} \\
\mid \\
\text { d. ek-ogo[vél] }\end{array}$ & & $* !$ & & & \\
\hline$\overbrace{\text { f. [ék-ógévél] }}^{\mathrm{H}_{1,2}}$ & $* !$ & & & & \\
\hline
\end{tabular}


The ranking IDENT-IO(H) $\gg \mathrm{OCP}-\mathrm{H}(\mu)$ also accounts for why two $\mathrm{H}$ tones juxtaposed across the prefix-root boundary—as in /é - jóðámáná/ $\rightarrow$ [éyə́ðámán] 'in the beans' (10) - are tolerated. IDENT-IO(H) would be violated by either deletion of one of the $\mathrm{H}$ tones or delinking of the initial root tone. Fusion is prohibited by MORPHDIS, so the two H tones co-exist. Previously, it was unclear whether IDENT-IO(H) or UNIFORMITY outranked the OCP-H for the lexical inputs with two $\mathrm{H}$ tones such as /HLH/. The above ranking dictates that those cases are resolved by fusion to [HHH] rather than deletion or fusion to [LLH], as we simply stipulated in (19). ${ }^{11}$

The behavior of $\mathrm{H}$ in the affixed forms is compatible with an analysis with specified input $\mathrm{H}$ with no specified input $\mathrm{L}$. To complete the argument that only $\mathrm{H}$ tone specification is necessary, consider an analysis with specified L for LHL nouns. $\mathrm{L}$ would be linked with the final vowel in the input, blocking $\mathrm{H}$ from spreading. However, if specified L blocked $\mathrm{H}$ spreading, the behavior of the locative prefixe lé-/ would be difficult to explain, because there, $\mathrm{H}$ spreading is blocked by another $\mathrm{H}$, but not by a L. This would lead to a problem with the behavior of L, as it would block $\mathrm{H}$ spreading only within the root. Beyond these arguments, Moro fits the pattern of other systems with a $\mathrm{H}$ vs. $/ \varnothing /$ contrast and exhibits characteristics of a pitch-accent language (Goldsmith 1987; Heny 1971; Hyman 1978, 1982, 2006; McCawley 1970). A single specification of $\mathrm{H}$ correlates with a particular melody. Furthermore, high tone spreading is a common pattern in these languages, occurring in Bantu languages such as Luganda (Hyman 1982) and Shona (Myers 1987; Odden 1980), and may be restricted by mechanisms which minimize spreading, but not by $\mathrm{L}$ specification. Restricting spreading with a lexical $\mathrm{L}$ is therefore not a viable analysis for Moro.

To summarize, the most common tone pattern for Moro nouns involves a $\mathrm{H}$ associated with the final TBU, the product of association to one TBU in the word with rightward spreading. The less common pattern is no $\mathrm{H}$ spreading. The difference between the two types is represented in the grammar by cophonologies that constrain or allow $\mathrm{H}$ spreading. Rightward $\mathrm{H}$ spreading is also observed with two affixes, one involving spreading to a suffix, and the other spreading from a prefix to the noun root. The latter case is partially blocked by the presence of another $\mathrm{H}$, providing evidence for a local OCP effect. Our analysis centered on considering various input specifications and showing how common tone patterns resulted from ranking of a small number of general constraints.

\section{Root-associated $\mathrm{H}$ on verbs}

The distribution of $\mathrm{H}$ on verbs is different from the distribution of $\mathrm{H}$ on nouns in a number of crucial respects. ${ }^{12}$ First, while $\mathrm{H}$ spreading on nouns is unbounded, $\mathrm{H}$

\footnotetext{
${ }^{11} \mathrm{We}$ are assuming that the same ranking constrains tonal behavior within roots and in longer words. It is, of course, possible to rerank constraints between levels under some versions of OT, in which case UNIFORMITY could be ranked lower than OCP-H within the root domain and higher in the prosodic word (Myers 1997), obviating the need for MORPH-DIS.

${ }^{12}$ The generalizations in this section were drawn from a database of 150 verb roots and their inflectional and derivational paradigms.
} 
spreading on verbs only extends the $\mathrm{H}$ a single mora to the right. Second, while nouns show tonal minimal pairs, indicating the importance of underlying representation, verbs do not. Because the position of tone is predictable based on the size and shape of syllables in the verb root, the position of $\mathrm{H}$ on verb roots can be derived from markedness constraints alone. This leads to our last asymmetry: while there are noun roots where every syllable surfaced with low tone, all verb roots with sufficiently heavy syllables bear $\mathrm{H}$ tone.

Despite these differences, there are similarities between the distribution of $\mathrm{H}$ on nouns and verbs in Moro. Like nouns, verbs roots exhibit rightward $\mathrm{H}$ spreading, though it is constrained differently. Furthermore, nouns show lexical distinctions based on $\mathrm{H}$ spreading. Finally, the constraint OCP-H (18), which was active in noun roots, also constrains the distribution of $\mathrm{H}$ on verbs, leading to tone competition, which we will address in Sect. 5 .

\subsection{Consonant-initial verb roots}

Most Moro verb roots take the shape (C)VC and (C)VCVC, abstracting away from geminate consonants, diphthongs, and codas. ${ }^{13}$ Following the root are 'extension' suffixes (applicative, passive, causative, reciprocal) and a final suffix that marks aspect. We begin with a discussion of consonant-initial verb roots.

Verb roots of the shape CVCVC (long roots) have a HH pattern on the root. This is illustrated with the $3^{\text {rd }}$ person imperfective verb form in (24), which is composed of a subject prefix /k-/, main clause/finite marker /a-/ and a final aspect vowel /-a/ or /-iə/ (/a/ may be raised to $[\Lambda]$ or [iə] with vowel harmony). The general pattern for this class is that $\mathrm{H}$ associates to the initial root vowel and spreads a single syllable to the right:

Long CVCVC roots with light syllables: $H H-L$

$\begin{array}{llllll}\text { a. k-a-távóð-a } & \text { 'spit' } & \text { c. } & \text { k-a-dógát-a } & \text { 'fix' } \\ \text { b. } & \text { k-a-kw'óréð-a } & \text { 'scratch' } & \text { d. } & \text { k-a-vóléð-a } & \text { 'pull' }\end{array}$

Short verbs of the shape CVC fall into two classes with respect to the distribution of $\mathrm{H}$. While all verbs of this shape have $\mathrm{H}$ on the root vowel, $\mathrm{H}$ only spreads onto the final vowel for certain verbs. This creates a lexical distinction between $\mathrm{H}-\mathrm{H}$ and $\mathrm{H}-\mathrm{L}$ melodies. ${ }^{14}$ The pattern with spreading to the final vowel is much more common, represented by 44 of 53 roots or $83 \%$ :

\footnotetext{
${ }^{13}$ There are also several verb roots composed of only a single consonant (ex. k-a-mm-a 'take'), and a few longer verbs whose segmental make-up suggests incorporation of lexicalized suffixes (ex: $k \Lambda^{-}$

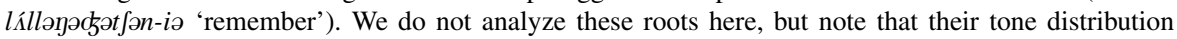
is consistent with the general analysis provided for the more canonical forms.

${ }^{14}$ There are two HL roots, $k \Lambda$ - $d \Lambda$ dəð- $\Lambda$ 'hiccup' and ka-və́dað- $a$ 'sweep,' versus ten roots with the HH spreading pattern, and none with LH. The difference between the HL and HH pattern is whether the $\mathrm{H}$ tone spreads or does not spread, which we assume to be lexically determined, and expressed by cophonologies like those for nouns above. However, the HL pattern in long verbs is empirically distinct from the H-L pattern in short verbs, as only the latter can be analyzed with non-finality, as we will show in (32).
} 
(25) Short CVC verbs with light syllables: $H-H$ and $H-L$

\section{$\mathrm{H}-\mathrm{H}$ pattern}

a. k- $\Lambda$-síð-í 'defecate'

b. k-a-wáð-á 'poke'

c. k-a-nát-á 'taste'

d. k-a-rát-ió 'clear land after harvest'

e. k-a-boán-á 'like, want'
H-L pattern

f.

g.

h.

i.

$\mathrm{j}$. k-a-tóð-a 'move'

k-a-váđ-a 'shave'

k-a-sát-a 'chew'

k-a-rát-iə 'kneel'

k-a-noán-a 'watch'

The table above includes several minimal or near-minimal pairs for the two classes. These demonstrate that segmental or quantity distinctions are not responsible for the tone differences.

Forms where $\mathrm{H}$ spreads a single TBU to the right $(24,25 \mathrm{a}-\mathrm{e})$, can be described as involving tone doubling. Tone doubling also occurs with extension suffixes, which are valence-changing suffixes such as causative, applicative or passive that occur between the root and the final aspectual vowel. In (26), the passive suffix, /-ən/ is shown attached to both long verb roots and short verb roots. This suffix triggers vowel harmony in the verb stem, and palatalization of final dental stops. ${ }^{15}$

\begin{tabular}{|c|c|c|c|c|}
\hline \multicolumn{5}{|c|}{ Verbs with extension suffixes } \\
\hline & & Imperfective & Imperfective passive & \\
\hline \multirow[t]{2}{*}{ HH-L } & a. & k-a-távóð-a & $\mathrm{k}-\Lambda$-t & 'spit' \\
\hline & b. & k-a-k ว́réð-a & k- $\Lambda$-kúríð-ən-iə & 'scratch' \\
\hline \multirow[t]{2}{*}{$\mathrm{H}-\mathrm{H}$} & c. & k-a-boán-á & 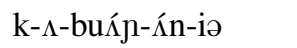 & 'like, want' \\
\hline & d. & k-a-wáð-á & 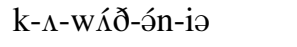 & 'poke' \\
\hline \multirow[t]{2}{*}{$\mathrm{H}-\mathrm{L}$} & e. & k-a-vád-a & 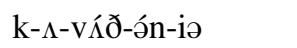 & 'shave' \\
\hline & f. & k-a-tóð-a & k- $\Lambda$-túð-ə́n-iə & 'move' \\
\hline
\end{tabular}

In long roots, $\mathrm{H}$ is already associated with two TBUs, satisfying tone doubling, and does not spread to the passive suffix (26a-b). In short roots, tone doubling spreads $\mathrm{H}$ to the extension suffix that follows the root. This applies regardless of whether tone doubling takes place when the extension suffix is not present. In (26c-d) $\mathrm{H}$ spreads to the following suffix regardless of whether it is final. In (26e-f), we see examples of roots that did not spread $\mathrm{H}$ to the final vowel. Surprisingly, $\mathrm{H}$ does appear on the passive suffix. The passive forms of short roots always have tone doubling, neutralizing the distinction between the two kinds of short roots. Thus, the lexical distinction we saw in (25) is not between verb roots with or without tone spreading, but rather, whether tone spreading can extend to the final vowel.

There is another group of verbs where tone doubling does not seem to apply. These roots all have a heavy first syllable, indicated with a dot between syllables in the root. $\mathrm{H}$ appears on the heavy syllable but does not spread, even to extension suffixes.

\footnotetext{
${ }^{15}$ The form $k_{\Lambda}$-t $t$ ívatf-ən-iə contains an applicative suffix /-t/ which is fused with the final dental fricative $/ ð /$, and palatalized in the passive. The active equivalent is [katavəta] 'he is spitting on (it)'.
} 


\begin{tabular}{|c|c|c|c|c|}
\hline \multirow{3}{*}{ HL-L } & & Imperfective & Imperfective passive & \\
\hline & a. & k-a-mwán.dəð-iə & k $\Lambda-\mathrm{m}^{\mathrm{W}} \Lambda$ n.dəð-ən-iə & 'ask' \\
\hline & b. & k-a-wón.datt-a & kı-wón.datf-ən-iə & 'see' \\
\hline \multirow{5}{*}{ H-L } & c. & $\mathrm{k}-\Lambda$-vín.d $d \partial^{j}$ f-iə & $\mathrm{k} \Lambda$-ván.d ${ }^{\mathrm{j}} \mathrm{t}$ f-ən-iə & 'hold' \\
\hline & d. & k-a-lálləృ-a & $n / a$ & 'run' \\
\hline & e. & k-a-wár.ð-a & 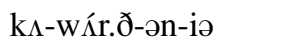 & 'write' \\
\hline & f. & k-a-lán.d-a & kı-lín.oz-ən-iə & 'close' \\
\hline & g. & $\mathrm{k}-\Lambda$-tun. $\mathrm{d}_{\Pi}-\Lambda$ & $n / a$ & 'cough' \\
\hline
\end{tabular}

This group of verbs includes both long and short roots. In both cases, $\mathrm{H}$ is confined to the heavy syllable, giving a HL pattern. ${ }^{16}$ Thus, tone doubling is sensitive to syllable weight.

Some analyses account for tone doubling with a rule or constraint requiring binary tone association (Hyman and Ngunga 1994; Odden 1998b; Bickmore 1999), while others induce general spreading, but constrain it to apply minimally (Cassimjee and Kisseberth 1998). Foot-based spreading is a popular alternative, and has been proposed for several languages including Shanghai and Lhasa Tibetan (Duanmu 1992, 1993), Sukuma (Bradshaw 1998), Lamba (Bickmore 2003; de Lacy 2001), N. Karanga Shona (Topintzi 2003), Yabem (Hansson 2004), Bambara (Leben 2003; Weidman and Rose 2006) and Kera (Pearce 2006). Whichever mechanism induces binary spreading, binarity is best defined in terms of moras. Assuming moraic codas, a CVC syllable contains two moras, and $\mathrm{H}$ would not be expected to spread beyond the heavy syllable.

The analyses differ in how they would prevent spreading beyond a moraic coda. In a foot-based analysis, a bimoraic foot, either (CV.CV.) or (CVC.), would restrict tone association, with its boundary preventing spreading to a following vowel whether the coda mora bears tone or not. ${ }^{17}$ In contrast, an analysis without feet would have to adopt an adjacency constraint to prevent skipping a following mora if it could not bear $\mathrm{H}$. We adopt the foot-based analysis as it unifies the behavior of CV.CV and CVC syllables instead of adding an adjacency requirement. The foot-based analysis also accounts for properties of vowel-initial roots, to be discussed in Sect. 4.2.

It would be preferable if there were independent arguments for feet, such as intensity or vowel duration, but there is a lack of clear evidence. Short verb roots typically contain a vowel that is longer than surrounding vowels: [kawáđá] 'poke', a property that is often associated with primary stress. Yet long verb roots typically contain a schwa in one of the two positions making vowel duration comparisons difficult. Verb roots with two schwas, such as [kalóvátfa] 'hide, keep' have a longer

\footnotetext{
${ }^{16}$ There are no verb roots with a heavy second syllable. This may be due to long verb roots being derived historically from extension suffixes that have become lexicalized. The second syllable ends in [ð], [t], or $[\mathrm{t}]$, which are each components of common extension suffixes.

${ }^{17}$ Note, though, that the coda does not always bear H, even when it is a possible TBU. For example, while nasals sometimes bear $\mathrm{H}$ as nuclei, as codas they rarely do. This can be seen in pitch tracks, which show a sharp drop on the nasal following the high-toned vowel in the forms in (27). These facts could be analyzed by positing a high-ranked $* \mathrm{H}$-NASAL, which prevents $\mathrm{H}$ tone from appearing on a $[+$ nasal] segment, to block spreading to nasal codas. When $\mathrm{H}$ is found on nasals, it may be there due to faithfulness to a prelinked input nasal $\mathrm{H}$.
} 
first vowel, while intensity measurements were inconclusive. The only long verb without a reduced vowel is [kadógáta] 'fix'. While the [o] is longer, it is not clear if this is due to the quality of the vowel or its position. Thus, while the duration facts are suggestive of a trochaic foot aligned with the left edge of the root, the evidence is not strong. However, adopting feet for tone distribution without additional evidence from other phonetic cues is also not without precedent (Leben 2003; Topintzi 2003).

As $\mathrm{H}$ is always associated with the leftmost syllable in the root, we follow Myers (1997) in using a constraint requiring $H$ to align with the left edge of the derived stem Align(H,L), defined in (28). ${ }^{18}$ The term derived stem (D-stem) consisting of the root and derivational affixes (see (29) below), is based on a similar constituent in Bantu languages such as Kinande (Downing 2000). In the Bantu literature, verbs are divided into constituents which serve as domains of particular phonological and morphological processes. The examples of Moro verbs provided so far lack derivational prefixes, but we will show in Sect. 5 that the H alignment constraint, ALIGN(H,L) effectively places $\mathrm{H}$ tone on a derivational prefix at the expense of tone on the root. The tone doubling pattern results from a constraint aligning the $\mathrm{H}$ tone domain with the right edge of the word, $\operatorname{ALIGN}(\mathrm{H}, \mathrm{R})$ - the same constraint we used with nouns in (13) — but with spreading constrained by foot boundaries. Foot boundaries are determined by a binary foot placed at the left edge of the derived stem, the result of two constraints, Align(FT,L) and FT-BIN. CRIspEdge (Itô and Mester 1994, 1999; Kawahara 2008) prevents $\mathrm{H}$ from crossing foot boundaries. These constraints are defined below:

\begin{tabular}{|c|c|c|}
\hline FOOT-BINARITY & $=$ FT-BIN & Feet are binary \\
\hline ALIGN(D-STEM I . & $=\operatorname{AL}(\mathrm{FT}, \mathrm{L})$ & $\begin{array}{l}\text { Align left edge of D-stem with left } \\
\text { edge of foot. }\end{array}$ \\
\hline LIGI & L) & $\begin{array}{l}\text { Align left edge of } \mathrm{H} \text { with left edge } \\
\text { of D-stem. }\end{array}$ \\
\hline $\operatorname{AligN}(\mathrm{H}, \mathrm{R}$; & $=A L(H, R)$ & $\begin{array}{l}\text { Align right edge of } \mathrm{H} \text { with right } \\
\text { edge of word. }\end{array}$ \\
\hline CRISPEDGE(H, FT) & $=\mathrm{CE}(\mathrm{H}, \mathrm{FT})$ & $\begin{array}{l}\mathrm{H} \text { tone domains cannot cross foot } \\
\text { boundaries. }\end{array}$ \\
\hline $\mathrm{M}-\mathrm{H}$ & & tem must associate $\mathrm{v}$ \\
\hline
\end{tabular}

There is no evidence that $\mathrm{H}$ is ever underlyingly associated with any particular position in verb roots, unlike nouns, since all verb roots bear $\mathrm{H}$ and its distribution is predictable. This is reminiscent of many 'predictable' Bantu tone languages (Odden 1989), where verb roots are lexically toneless and $\mathrm{H}$ tone patterns are associated with particular grammatical forms. For Moro, we introduce a general constraint requiring

\footnotetext{
${ }^{18}$ Like Moro, Shona associates $\mathrm{H}$ to the leftmost TBU in a phonological domain. Yet they differ because the $\mathrm{H}$ in Shona is associated with the leftmost TBU in the phonological word, equivalent to the entire Moro verb, rather than the D-stem. In the analysis of Myers 1997, the H is a floating tone in the input. We simplify the input by requiring $\mathrm{H}$ within the $\mathrm{D}$-stem with a constraint.
} 
the derived stem to have a $\mathrm{H}$ tone: STEM-H. ${ }^{19}$ The schema of the Moro verb is shown below, with brackets delineating the D-stem:

(29) SM-TENSE-CLASS-CLAUSE-OM-[PROG-DUR/ITER-ROOT-EXT D-STEM]ASP/MOOD-OM-INST-LOC

In Sect. 4.2 we will show why STEM-H should be defined relative to the D-stem, and provide additional support for the progressive and durative/iterative reduplicative prefixes being part of the D-stem. Further evidence is discussed in Sect. 5.3.

To account for tone doubling, STEM-H, AL $(\mathrm{H}, \mathrm{L})$ and $\mathrm{CE}(\mathrm{H}, \mathrm{FT})$ are ranked above $\mathrm{AL}(\mathrm{H}, \mathrm{R})$, as shown in $(30 \mathrm{~b}-\mathrm{d})$. The D-stem is demarcated by brackets in the input, and feet by parentheses in the output. Failure to spread $\mathrm{H}$ in (30b) violates $\mathrm{AL}(\mathrm{H}, \mathrm{R})$ worse than the winning candidate, but spreading to the final TBU violates $\mathrm{CE}(\mathrm{H}, \mathrm{FT})$, as $\mathrm{H}$ crosses a foot boundary (30c). If there is no $\mathrm{H}$ on the first TBU of the D-stem (or root), $\mathrm{AL}(\mathrm{H}, \mathrm{L})$ is violated (30d). Having no $\mathrm{H}$ as in $(30 \mathrm{e})$ violates STEM-H. Candidates (30f) and (30g) violate $\mathrm{AL}(\mathrm{FT}, \mathrm{L})$ and FT-BIN respectively, but also violate other constraints. We assume that these two constraints are high-ranked due to the absence of arguments otherwise. This ranking will be confirmed later for AL(FT,L). All candidates we consider from now on will have a binary foot left-aligned with the edge of the D-stem, and we will no longer show these constraints in tableaux unless necessary.

(30) Ranking accounting for tone doubling: STEM-H, $\mathrm{AL}(\mathrm{H}, \mathrm{L}), \mathrm{CE}(\mathrm{H}, \mathrm{FT}) \gg$ $\mathrm{AL}(\mathrm{H}, \mathrm{R})$

\begin{tabular}{|c|c|c|c|c|c|c|c|}
\hline \multicolumn{2}{|c|}{ /k-a-[vəleð]-a/ } & FT-BIN & $\mathrm{AL}(\mathrm{FT}, \mathrm{L})$ & STEM-H & $\mathrm{AL}(\mathrm{H}, \mathrm{L})$ & $\mathrm{CE}(\mathrm{H}, \mathrm{FT})$ & $\mathrm{AL}(\mathrm{H}, \mathrm{R})$ \\
\hline$\varpi \mathrm{a}$. & ka(válé)ða & & & & & & $*$ \\
\hline b. & ka(vále)ða & & & & & & $* * !$ \\
\hline c. & ka(válé)ðá & & & & & $* !$ & \\
\hline d. & ka(vəlé)ða & & & & $* !$ & & $*$ \\
\hline e. & $\mathrm{ka}($ vəle)ða & & & $* !$ & & & \\
\hline f. & kavə(léðá) & & $* !$ & & $*$ & & \\
\hline g. & ka(vá)leða & $* !$ & & & & & $* *$ \\
\hline
\end{tabular}

This ranking accounts for tone doubling on the long $(\mathrm{HH})$ verb roots, including the lack of spreading to suffixes, which occur following the right edge of the foot. ${ }^{20}$

The second issue in the analysis of $\mathrm{H}$ on verb roots is accounting for the lexical distinction between the short verb roots with and without tone doubling, as in (25). This is accomplished with the constraint NON-FINALITY:

\section{NON-FINALITY}

Do not associate the final TBU of a prosodic domain with $\mathrm{H}$ tone.

\footnotetext{
${ }^{19}$ It is possible to have an underlying $\mathrm{H}$ tone specified but its position would still be regulated by the same constraints; it would simply incur more IDENT-IO(H) violations if shifted.

${ }^{20}$ We assume that all candidates with spreading violate $* \mathrm{H}$, but this constraint is low-ranked below $\mathrm{AL}(\mathrm{H}, \mathrm{R}) .{ }^{*} \mathrm{H}$ will only play a role with the two exceptional HL roots, which would require a lexicallyspecific ranking of $\mathrm{AL}(\mathrm{H}, \mathrm{R})$ ranked below $* \mathrm{H}$. Note that these roots begin with $\mathrm{H}$ tone, as dictated by STEM-H and AL(H,L).
} 
The prosodic domain here is the prosodic word. NON-FINALITY prevents $\mathrm{H}$ tone from associating with the final vowel of the prosodic word. This constraint is ranked below $\mathrm{AL}(\mathrm{H}, \mathrm{R})$ for doubling cases (32a), and above it for non-doubling (32b). STEM-H is ranked higher than the lower ranked of these two constraints to ensure that at least one high tone appears on the verb stem.

a. Short $H-H$, tone doubling to final vowel: $\operatorname{AL}(\mathrm{H}, \mathrm{R}) \gg \mathrm{NONFINAL}$

\begin{tabular}{|c||c|c|c|c|c|}
\hline$/$ k-a-[wað]-a/ & $\mathrm{AL}(\mathrm{H}, \mathrm{L})$ & $\mathrm{CE}(\mathrm{H}, \mathrm{FT})$ & $\mathrm{STEM}-\mathrm{H}$ & $\mathrm{AL}(\mathrm{H}, \mathrm{R})$ & NONFINAL \\
\hline \hline a. ka(wáða) & & & & $* !$ & \\
\hline$\sigma$ b. ka(wáðá) & & & & & $*$ \\
\hline c. ka(waða) & & & $* !$ & & \\
\hline
\end{tabular}

b. Short H-L, no tone doubling to final vowel: NONFINAL $\gg \operatorname{AL}(H, R)$

\begin{tabular}{|c||c|c|c|c|c|}
\hline$/$ k-a-[vað]-a/ & $\mathrm{AL}(\mathrm{H}, \mathrm{L})$ & $\mathrm{CE}(\mathrm{H}, \mathrm{FT})$ & $\mathrm{STEM}-\mathrm{H}$ & NONFINAL & $\mathrm{AL}(\mathrm{H}, \mathrm{R})$ \\
\hline \hline a. ka(váða) & & & & & $*$ \\
\hline b. ka(váðá) & & & & $* !$ & \\
\hline c. ka(vaða) & & & $* !$ & & \\
\hline
\end{tabular}

The fact that short roots exhibit a lexical distinction while long roots do not falls out naturally from our analysis, as tone doubling only spreads $\mathrm{H}$ to the final vowel in short roots.

Another advantage of this approach is that it correctly predicts that the lexical distinction in spreading is neutralized with extension suffixes, as we saw in (26c-f):

Short verb roots: neutralization in spreading to extension suffixes

\begin{tabular}{|c|c|c|c|c|c|}
\hline 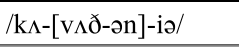 & $\mathrm{AL}(\mathrm{H}, \mathrm{L})$ & $\mathrm{CE}(\mathrm{H}, \mathrm{FT})$ & STEM-H & NONFINAL & $\mathrm{AL}(\mathrm{H}, \mathrm{R})$ \\
\hline 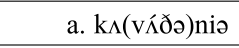 & & & & & $* * !$ \\
\hline$\sigma \quad$ b. kn(víðá)niə & & & & & $*$ \\
\hline
\end{tabular}

Because extension suffixes are non-final, tone doubling is expected.

Finally, consider the tone pattern characteristic of verb roots with initial heavy syllables, which are always HL or H-L. Because the heavy syllable is bimoraic, spreading to the following vowel incurs a violation of $\mathrm{CE}(\mathrm{H}, \mathrm{FT})(34 \mathrm{~b})$. A passive form is shown to remove any potential issues with Non-FINALITY. Candidate (34d) shows that failure to place a $\mathrm{H}$ tone on the initial syllable is more important than tone being aligned closer to the right edge, an additional argument for $\operatorname{AL}(H, L) \gg \operatorname{AL}(H, R)$. We have indicated a second foot, but iterative feet are not required. $\mathrm{CE}(\mathrm{H}, \mathrm{FT})$ will still rule out extra spreading beyond the foot boundary of the first foot. 
(34) Heavy syllable verb roots: $\mathrm{AL}(\mathrm{H}, \mathrm{L}) \gg \mathrm{AL}(\mathrm{H}, \mathrm{R})$

\begin{tabular}{|c|c|c|c|c|c|c|}
\hline & $/ k \Lambda$-[wən.d $\left.\Lambda t \int-ə n\right]-i ə /$ & $\mathrm{CE}(\mathrm{H}, \mathrm{FT})$ & STEM-H & NONFINAL & $\mathrm{AL}(\mathrm{H}, \mathrm{L})$ & $\mathrm{AL}(\mathrm{H}, \mathrm{R})$ \\
\hline & a. $\mathrm{k} \Lambda$ (wən) $(\mathrm{d} \Lambda \mathrm{t} ə)$ niə & & $* !$ & & & \\
\hline & b. kı(wón)(dর́tfá)niə & $* !$ & & & & * \\
\hline$\sigma$ & 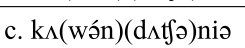 & & & & & $* * *$ \\
\hline & d. k^(wən)(dর́tfá)niə & & & & $* !$ & $*$ \\
\hline
\end{tabular}

The foot-based analysis that was utilized for light syllable roots extends naturally to roots with a heavy syllable. A verb form is derived with a single $\mathrm{H}$ tone on the heavy syllable, but without a constraint directly requiring $\mathrm{H}$ tone to associate to a heavy syllable.

This section has provided an overview of the tone melodies associated with consonant-initial verb roots with one and two syllables. These cases comprise 96/150 $(64 \%)$ of the attested verbs. While the same constraint, $\operatorname{AL}(\mathrm{H}, \mathrm{R})$, which produced spreading in nouns also does so in verbs, in verbs this constraint is restricted by binary feet, resulting in tone doubling. As with nouns, two lexical classes are analyzed via cophonologies with a single switch in constraint ranking. Moreover, instead of assuming an input $\mathrm{H}$ tone, a constraint requires the verb stem to have $\mathrm{H}$, whose position is determined by other constraints.

\subsection{Vowel-initial verb roots}

Vowel(V)-initial roots with one or two vowels are also common, represented by $30 / 150(20 \%)$ of attested verb forms. The distribution of lexical $\mathrm{H}$ on these roots is distinctive: while Consonant(C)-initial verb roots begin with $\mathrm{H}$, $\mathrm{V}$-initial roots do not. ${ }^{21}$ Yet just as $\mathrm{C}$-initial long roots exhibited tone doubling to the second root syllable, $\mathrm{H}$ also appears on the second syllable of $\mathrm{V}$-initial roots. This $\mathrm{H}$ does not spread, so $\mathrm{V}$-initial long roots have the melody LH-L:

V-initial long verb roots with light syllables: LH-L

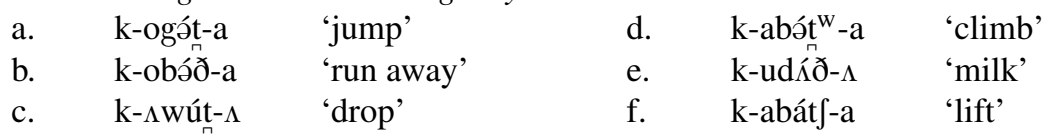

Note that the prefix /a-/, which marks main clauses and normally precedes the root, is deleted by a regular hiatus process in which the first of two adjacent vowels deletes: /k-a-obəð-a/ $\rightarrow$ [kobə́ða]. Although the surface segmental shape of these verb forms resembles the consonant initial short verb root forms (with no spreading), the initial onset is a subject agreement prefix, not a root consonant.

\footnotetext{
${ }^{21}$ There are five roots that show a single $\mathrm{H}$ tone on an initial vowel and no spreading: $k$-oás- $a$ 'wash', $\eta$ $o ́ l$ - $a$ 'drip (of water)', $k$ - ́njət- $\Lambda$ 'show', $k$-ákəm- $a$ 'judge' and $k$-álab-a 'play'. We analyze these as lexical exceptions (the final two are borrowings from Arabic). Like the $\mathrm{C}$-initial exceptional roots, they show the pattern of $\mathrm{H}$ tone on the first root TBU with no spreading.
} 
Short V-initial roots also show a different tone pattern, sharing with the long roots the lack of $\mathrm{H}$ on $\mathrm{V}$-initial syllables. In fact, these verbs occur without any $\mathrm{H}$ at all in the imperfective:

V-initial short verb roots with light syllables: L-L
a. k-al-a 'slice'
c. k-ur- $\Lambda$ 'blow (intr.)'
b. k-oað-a 'mill, grind'
d. k-oar-a
'badmouth'

These are the only verb forms we have seen so far without $\mathrm{H}$ tone. In summary, while $\mathrm{C}$-initial roots fall into two general patterns, spreading $(\mathrm{HH}-\mathrm{L} / \mathrm{H}-\mathrm{H})$ and no spreading (HL-L/H-L), V-initial roots have distinct patterns: LH-L for long roots, and L-L for short roots.

When the passive suffix is attached to V-initial roots, it does not bear $\mathrm{H}$ tone with long roots, but does have a $\mathrm{H}$ tone with short roots, even though the initial vowel still lacks $\mathrm{H}$ tone:

\begin{tabular}{|c|c|c|}
\hline Imperfective & Imperfective passive & \\
\hline k-ogát-a & k-ugátf-ən-iə & ‘jump’ \\
\hline k-obə́ð-a & k-ubáð-ən-iə & 'move' \\
\hline k-al-a & k- 1 l-ə́n-iə & 'slice' \\
\hline k-оað-a & k-uıð-ว́n-iə & 'mill, grind' \\
\hline
\end{tabular}

The V-initial long roots $(37 \mathrm{a}, \mathrm{b})$ do not show tone doubling to the extension suffix, the same behavior as for the long $\mathrm{C}$-initial verbs. $\mathrm{H}$ only emerges on the extension suffix in short forms, similar to the pattern observed with H-L CVC verb roots (26).

Onsetless initial syllables resist $\mathrm{H}$ tone in various languages, including Ciyao (Ngunga 2000), Kikerewe (Odden 1995), Kikuria (Mwita 2008), Yoruba (Orie 2000), and Zinza (Odden 2006). This phenomenon has been analyzed as an effect of extraprosodicity. Odden (2006) proposes that the initial vowel is not part of the prosodic word. Downing (2000) translates the notion of extraprosodicity into a mismatch between the morphological stem and the prosodic stem. Initial vowels of phonological stems also fail to participate in reduplication and do not count for minimality effects in these languages. However, the Moro data pose problems for an account based on extraprosodicity.

First, the tone pattern for long roots in Moro suggests that the onsetless syllable is part of the foot: /k-(ubə́)ð-ən-iə/. If it were not, the syllable following the root would be incorporated into the foot, predicting that $\mathrm{H}$ would spread onto extension suffixes: */k-u(báð-á)n-iə/. H does spread to the extension suffix in short roots, where it constitutes the second syllable of a foot. If the first syllable is parsed into a foot, it cannot be extraprosodic by definition. The second problem with an analysis based on extraprosodicity is that if a V-initial syllable is heavy, it bears $\mathrm{H}$ tone. That is, they pattern just like consonant-initial verb roots with an initial heavy syllable: 


\begin{tabular}{|c|c|c|}
\hline Imperfective & Imperfective passive & \\
\hline k-índ-iə & k-índ-ən-iə & 'catch' \\
\hline k-áff-a & k-ńff-ən-iə & 'build, shoot' \\
\hline k-óndət-a & $\mathrm{n} / \mathrm{a}$ & 'dry (int.)' \\
\hline
\end{tabular}

To account for this distinction, light onsetless syllables would have to be extraprosodic while heavy onsetless syllables would not be. Therefore, an extraprosodic analysis is not compatible with the Moro facts.

As there is an observed distinction between $\mathrm{V}$ and $\mathrm{VC}$ syllables in their ability to host tone, and given that there is a distinction between light $\mathrm{CV}$ and heavy CVC syllables with respect to tone spreading, we propose a unified analysis of $\mathrm{H}$ distribution based on prominence of syllable types. The pattern in Moro is similar to stress systems that show both rime and onset sensitivity (de Lacy 2001; Goedemans 1998; Gordon 2005). In these languages, syllable types that preferentially bear $\mathrm{H}$ tone (or stress) fall in a scale: $(\mathrm{C}) \mathrm{VC}>\mathrm{CV}>\mathrm{V}$, where a light onsetless syllable is a dispreferred stress bearer. We employ a constraint against light onsetless syllables bearing high tone, after Kawu (2000). See de Lacy (2001) and Gordon (2005) for different formulations of the same basic restriction:

\section{$*[\mathrm{~V}]_{\sigma}-\mathrm{H} \quad$ Light onsetless syllables cannot bear high tone in D-stem.}

The domain of this constraint is the D-stem, thereby excluding the initial subject marker as an onset for purposes of licensing $\mathrm{H}$ tone. A similar type of word-internal vowel-initial restriction is found in Kinande reduplication (Downing 2000; Mutaka 1994; Mutaka and Hyman 1990), in which root-initial vowels are not included as part of the reduplicant, despite having onsets.

There is additional evidence that the domain of the constraint in (39) is the D-stem rather than the root. Onsets outside the $\mathrm{D}$-stem cannot license $\mathrm{H}$ tone, but those within the D-stem can. There is an imperfective prefix / $\mathrm{v}-/$ which occurs only with vowelinitial roots that do not contain a labial consonant or a round vowel. The meaning of this prefix is not clear-it occasionally has a progressive reading. If / $/ \mathrm{-} /$ is present, the tone distribution is identical to that of consonant-initial roots, $\mathrm{H}-\mathrm{H}$ with short roots and $\mathrm{HH}$ with long roots:

\begin{tabular}{|c|c|c|c|}
\hline Short roots & & & Long roots \\
\hline k-a-v-áj-á & 'die' & d. & $\mathrm{k}-\Lambda$-V-1́líð- $\Lambda$ \\
\hline k-a-v-ác-á & 'cry' & e. & $\mathrm{k}-\Lambda$-V-ńgár-iə \\
\hline k- $\Lambda$-V-íd-iá & 'fall down' & f. & k-a-v-álə́n-a \\
\hline
\end{tabular}

Unlike the subject marker prefix $/ \mathrm{k}-/$, the $/ \mathrm{v}-/$ prefix licenses $\mathrm{H}$ tone on the initial root vowel. It is not the case that the $/ \mathrm{v}-/$ prefix is specified for $\mathrm{H}$ tone underlyingly which is then realized on the initial vowel. Prefixes that do bear $\mathrm{H}$, such as the preverbal object marker, show different behavior. A $\mathrm{H}$ tone associated with these prefixes cannot appear on the root vowel, even if vowel hiatus results in the consonant from the object prefix serving as an onset to the initial root vowel: /k-a-né-abatf-a/ $\rightarrow$ [kánabatfa] 's/he is about to lift me'. This is the opposite pattern of the /v-/ prefix. The difference 
between these two prefixes, in addition to the phonological sensitivity of / $\mathrm{v}-/$ to the segmental properties of the root, indicate that /v-/ is inside the D-stem, where it can provide an onset for the root and license $\mathrm{H}$ on the initial vowel. In contrast, the object marker is outside the D-stem; we return to the analysis of $\mathrm{H}$ associated with object markers in Sect. 5.

We now turn to the formal analysis of $\mathrm{H}$ distribution on $\mathrm{V}$-initial roots. The LH-L pattern of long $\mathrm{V}$-initial roots indicates that $*[\mathrm{~V}]_{\sigma}-\mathrm{H}$ outranks $\mathrm{AL}(\mathrm{H}, \mathrm{L})$, as $\mathrm{H}$ tone is not left-aligned with the D-stem. In addition, $\operatorname{AL}(\mathrm{FT}, \mathrm{L})$ must also outrank $\operatorname{AL}(\mathrm{H}, \mathrm{R})$, as an output with a foot misaligned with the root edge must be excluded. We assumed this ranking before, but these candidates confirm it. The onset /k-/ in these examples is outside the D-stem and not parsed into the foot.

(41) Long V-initial verb roots: $*[\mathrm{~V}]_{\sigma}-\mathrm{H} \gg \mathrm{AL}(\mathrm{H}, \mathrm{L})$; $\mathrm{AL}(\mathrm{FT}, \mathrm{L}) \gg \mathrm{AL}(\mathrm{H}, \mathrm{R})$

\begin{tabular}{|c|c|c|c|c|c|c|}
\hline /k-[oget ] $]-\mathrm{a} /$ & $\mathrm{AL}(\mathrm{FT}, \mathrm{L})$ & STEM-H & $*[\mathrm{~V}]_{\sigma}-\mathrm{H}$ & $\mathrm{CE}(\mathrm{H}, \mathrm{FT})$ & $\mathrm{AL}(\mathrm{H}, \mathrm{L})$ & $\mathrm{AL}(\mathrm{H}, \mathrm{R})$ \\
\hline a. k-(ogə)t-a & & $* !$ & & & & \\
\hline$\sigma \quad$ b. k-(ogá)t-a & & & & & * & $*$ \\
\hline c. k-(ógó)t-t-a & & & $* !$ & & & $*$ \\
\hline d. k-o(gát-á) & *! & & & & * & \\
\hline e. k-(ogót )-á & & & & $* !$ & $*$ & \\
\hline
\end{tabular}

The ranking above accounts for the fact that tone doubling does not apply in V-initial long forms. This ranking extends without modification to account for $\mathrm{V}$-initial verbs with extension suffixes, which also lack tone doubling, due to $\mathrm{CE}(\mathrm{H}, \mathrm{FT})$.

The lack of high tone on V-initial short verbs with light syllables means that $*[\mathrm{~V}]_{\sigma}-\mathrm{H}$ must be ranked above STEM-H. The aspectual final suffix is outside the D-stem, so tone appearing on this affix does not satisfy STEM-H, and the optimal candidate is one with no tone, due to (42b) incurring a violation of AL(H,L). Candidate (42b) escapes this by virtue of having no tone at all. D-stem boundaries are represented in the input with brackets:

(42) Short V-initial verb roots: $*[\mathrm{~V}]_{\sigma}-\mathrm{H} \gg \mathrm{STEM}-\mathrm{H}$

\begin{tabular}{|c|c|c|c|c|c|c|}
\hline$/$ k-[oað]-a/ & AL(FT,L) & $\mathrm{CE}(\mathrm{H}, \mathrm{FT})$ & $*[\mathrm{~V}]_{\sigma}-\mathrm{H}$ & $\mathrm{STEM}-\mathrm{H}$ & $\mathrm{AL}(\mathrm{H}, \mathrm{L})$ & $\mathrm{AL}(\mathrm{H}, \mathrm{R})$ \\
\hline$\sigma$ a. k-(oað-a) & & & & $*$ & & \\
\hline b. k-(oað-á) & & & & $*$ & $* !$ & \\
\hline c. k-(oáð-á) & & & $* !$ & & & \\
\hline
\end{tabular}

Note that this ranking does not make any specific prediction as to the ranking of STEM-H and $\mathrm{AL}(\mathrm{H}, \mathrm{L})$. However, the fact that $\mathrm{H}$ emerges on extension suffixes in short V-initial verbs provides an argument that STEM-H does indeed outrank $\mathrm{AL}(\mathrm{H}, \mathrm{L})$ : 
(43) Short V-initial verb roots with extension suffix: $\mathrm{STEM}-\mathrm{H} \gg \operatorname{AL}(\mathrm{H}, \mathrm{L})$

\begin{tabular}{|c|c|c|c|c|c|c|c|}
\hline & /k-[u^ð-ən]-іə/ & $\mathrm{AL}(\mathrm{FT}, \mathrm{L})$ & $\mathrm{CE}(\mathrm{H}, \mathrm{FT})$ & $*[\mathrm{~V}]_{\sigma}-\mathrm{H}$ & STEM-H & $\mathrm{AL}(\mathrm{H}, \mathrm{L})$ & $\mathrm{AL}(\mathrm{H}, \mathrm{R})$ \\
\hline & a. k-(u^ð-ə)n-iə & & & & *! & & \\
\hline$\sigma$ & 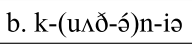 & & & & & $*$ & $*$ \\
\hline & c. k-(uńð-ó)n-iə & & & $* !$ & & & $*$ \\
\hline & d. k-(u^ð-ə́)n-íə & & $* !$ & & & * & \\
\hline
\end{tabular}

The constraint STEM-H requires $\mathrm{H}$ to appear on the D-stem (43a), but $*[\mathrm{~V}]_{\sigma}-\mathrm{H}$ prevents it from appearing on the onsetless root vowel (43c), which would satisfy Align(H,L). However, $\mathrm{H}$ tone appears on the extension suffix, part of the D-stem, to satisfy STEM-H, despite the fact that an overt H violates Align(H,L) (43b).

We have provided two different explanations for the lack of $\mathrm{H}$ tone on the final aspectual vowel. For C-initial roots, NON-FINALITY was proposed to prevent $\mathrm{H}$ tone spreading onto the final vowel (32b). On the other hand, in monosyllabic V-initial roots, STEM-H prevents a single realization of $H$ tone on the final suffix (42). While the two cases are similar, they are empirically different and cannot receive a unified analysis. C-initial forms show variation with respect to whether tone doubling applies, but V-initial forms do not. If NON-FINALITY were used to explain the lack of final $\mathrm{H}$ on short $\mathrm{V}$-initial roots, this would predict a $\mathrm{H}-\mathrm{L}$ melody when the / $\mathrm{v}-/$ prefix is added. Thus, the lack of final $\mathrm{H}$ in these forms must be due to the absence of $\mathrm{H}$ on the root. The / $\mathrm{v}-/$ prefix is responsible for licensing $\mathrm{H}$ tone on the root which only then can be spread to the final vowel.

This concludes our discussion of lexical high tone association within verb roots. The attested tone patterns are summarized below:

\section{$H$ tone melodies on verbs}

\begin{tabular}{l|l|l|l|l|l}
\hline Type of root & & Long & Long + Ext & Short & Short + Ext \\
\hline Light syllables & C-initial & HH-L & HH-L-L & H-L / H-H & H-H-L \\
\hline & V-initial & LH-L & LH-L-L & L-L & L-H-L \\
\hline Heavy syllables & C- or V-initial & HL-L & HL-L-L & H-L & H-L-L \\
\hline
\end{tabular}

First, we proposed that specifying underlying tone is unnecessary, as the distribution of $\mathrm{H}$ tone follows from general constraints on tone distribution, and a basic requirement that $\mathrm{H}$ tone appear in the D-stem. Second, C-initial roots with light syllables show tone doubling, which we analyzed as foot-bound spreading. Short roots show lexical variation in whether $\mathrm{H}$ tone can appear on the final aspectual vowel, which is outside the D-stem. This was analyzed as lexically-specific constraint ranking of Non-FINALITY with $\mathrm{Al}(\mathrm{H}, \mathrm{R})$. Third, V-initial roots do not have $\mathrm{H}$ on the initial vowel. We tied this to a general constraint against onsetless light syllables bearing tone, which outranks STEM-H, the constraint requiring $\mathrm{H}$ tone to appear in the Dstem, and $\operatorname{AL}(\mathrm{H}, \mathrm{L})$, requiring $\mathrm{H}$ tone on the first TBU of the D-stem. STEM-H also plays a role in preventing $\mathrm{H}$ tone from appearing on the aspectual final vowel with short VC roots. Finally, heavy syllables show a type of tone attraction in that $\mathrm{H}$ tone appears exclusively on them and fails to spread to any following vowels. This was a 
direct result of alignment and foot-based spreading constraints. Typologically, Moro illustrates a unique case of foot-bound tone spreading that also displays sensitivity to a three-way distinction in the size of syllables hosting tone.

The constraint rankings are summarized below. The double-sided arrow represents the fact that there are verbs attesting both rankings of NON-FINALITY and AL $(H, R)$ in our analysis:

\section{(45) Summary of constraint rankings for D-stem H tone distribution}

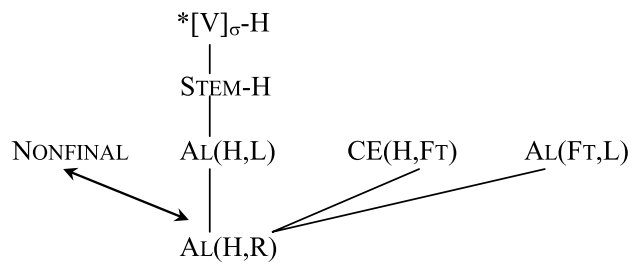

Besides accounting for the variation in the distribution of $\mathrm{H}$ on the verb stem, this section has provided evidence for a morphological domain, the D-stem, in which $\mathrm{H}$ is privileged. In the next section will expand our investigation to include $\mathrm{H}$ lexically associated with verbal affixes.

\section{High-tone competition}

The discussion of the lexical realization of tone in Sect. 3 and Sect. 4 centered around high tone spread in Moro, including the positional realization of high tone within the word and the D-stem respectively. This section introduces a new phenomenon that we term tone competition in morphologically more complex verb forms. $\mathrm{H}$ tones associated with affixes compete for realization, both with one another and with $\mathrm{H}$ associated with the D-stem. The central generalization is that only a single $\mathrm{H}$ tone may be realized, an OCP-type effect, within a larger domain called the macrostem.

\subsection{Tone competition with affixes}

When high-toned affixes are added to the verb stem, the $\mathrm{H}$ associated with the Dstem is not realized. Thus, affixal $\mathrm{H}$ always overrides D-stem $\mathrm{H}$ tone. There are three examples of this phenomenon in Moro.

The first example occurs with durative/iterative reduplication, which only occurs on verb roots with punctual Aktionsart and signifies continuous or repetitive action. The reduplicant, which always bears $\mathrm{H}$ tone, is /CáC-/ with consonant-initial roots and /V́kk-/ with vowel-initial roots. When reduplication occurs, no $\mathrm{H}$ tone emerges on the root: ${ }^{22}$

\footnotetext{
${ }^{22}$ The reduplicated consonant is voiced, while the initial consonant of the root is geminated and realized as voiceless if obstruent (except/ð/, which has a voiceless counterpart only word-finally). For vowel-initial roots, the first vowel of the root is copied.
} 
(46) Durative/Iterative reduplication

Punctual

a. ka-ðáw-á

b. ka-tòð-a

c. ka-távóð-a

d. ka-k ${ }^{\mathrm{w}}$ əréð-a

e. ka-vóléð-a

f. k-ogát-a

g. k-ál-a

\section{Durative/Iterative}

ka-ðáð-ðəw-a

'he's poking'

ka-dát-toð-a

ka-dát-tavəð-a

ka-gák-k ${ }^{\mathrm{w}}$ əreð-a

ka-váf-fəleð-a ${ }^{23}$

k-ókk-ogət-a

k-ákk-al-a 'he's waking up'

'he's spitting'

'he's scratching'

'he's pulling'

'he's jumping'

'he's slicing'

This is a putative example of $\mathrm{H}$ tone competition, as the $\mathrm{H}$ that is normally realized on the root is not realized in the presence of the $\mathrm{H}$ on the reduplicant.

The second case of competition is with preverbal object markers, ${ }^{24}$ found in imperfective and subordinate verbs (except 3PL), which show the same effect as the durative/iterative prefix; these morphemes bear $\mathrm{H}$ tone, and no tone emerges on the root:

\begin{tabular}{|c|c|c|}
\hline 3SG (non-human) & ka-vóléð-a & 's/he's going to pull... \\
\hline $1 \mathrm{SG}$ & ka-jə́-vəleð-a & ...me' \\
\hline $2 \mathrm{SG}$ & ka-yá-vəleð-a & ...you' \\
\hline 3SG (human) & ka-yó-vəleð-a & ..him/her' \\
\hline 1DUAL INCL & ká-ńdə-vəleð-a & ...us two' \\
\hline 1PL EXCL & ka-pə́-vəleð-álánda & ...us' \\
\hline 1PL INCL & ká-ńdə-vəleð-a-ŕ & ...us' \\
\hline $2 \mathrm{PL}$ & ká-ńdə-vəleð-a & ...you' \\
\hline 3PL & ka-vóléð-a-lo & ...them' \\
\hline
\end{tabular}

Some comments should be made about the realization of tone in (47): the 1PL object marker /ńdə/ bears $\mathrm{H}$ tone on the nasal which spreads onto the preceding vowel, a pattern also found with the nasal-consonant initial verb ká-ńdr-a 's/he is sleeping'. The exceptional postverbal $3^{\text {rd }}$ plural object marker /-lo/ does not trigger $\mathrm{H}$ deletion on the root. We have only shown consonant-initial roots above; we reserve discussion of the position of $\mathrm{H}$ in vowel-initial roots until Sect. 5.3 (though recall the brief discussion of this matter in Sect. 4.2).

The final case of tone competition comes from the perfective suffix /-ó/. Again, it prevents $\mathrm{H}$ from appearing on the root. This is the case regardless of the tone pattern of the verb:

(48) Tone competition in perfective verb forms

Imperfective Perfective
a. k-a-yál-á
k-a-yal-ó
'yawn'
b. ka-k ${ }^{\mathrm{w}}$ ว́réð-a ka-k ${ }^{\mathrm{w}}$ əreð-ó 'scratch'

Imperfective Perfective

c. ka-wárð-a ka-warð-ó

d. ka-mwándəð-iə ka-m andəð-ó 'ask'

\footnotetext{
${ }^{23}$ This form was also given as ka-váf-fərleð-a.

${ }^{24}$ We refer to dependent morphemes marking objects simply as pre- and postverbal object markers, staying neutral as to whether they are agreement affixes or incorporated object pronouns. One relevant consideration is that they cannot occur with overt object noun phrases.
} 
In summary, two high-toned preverbal morphemes, durative/iterative reduplication (46) and preverbal object markers (47) prevent $\mathrm{H}$ tone from appearing on the root, as does the perfective suffix in (48).

When high-toned affixes combine on the same side of the verb form, the edgemost affix bears $\mathrm{H}$ tone. Thus, when object prefixes combine with durative/iterative reduplication, the object prefix retains high tone, but no tone appears on the reduplicant or the root:

$$
\begin{aligned}
& \text { Preverbal object markers + Iterative/Durative reduplication } \\
& \begin{array}{lll}
\text { a. ka-yó-ðað-ðəw-a } & \text { 'he's poking her' } \\
\text { b. } & \text { ka-jó-gak-koreð-a } & \text { 'he's scratching me' } \\
\text { c. } & \text { ká-ńdə-vaf-fəleð-a } & \text { 'he's pulling us' }
\end{array}
\end{aligned}
$$

These forms follow the generalization that only a single affixal $\mathrm{H}$ can appear.

\begin{tabular}{|c|c|c|c|}
\hline Perfective & $\begin{array}{l}\text { Durative/iterative } \\
\text { perfective }\end{array}$ & $\begin{array}{l}\text { Durative/iterative } \\
\text { imperfective }\end{array}$ & \\
\hline ka-ðəw-ó & ka-ðað-ðəw-ó & ka-ðáð-ðəw-a & 'poke' \\
\hline ka-toð-ó & ka-dat-toð-ó & ka-dát-toð-a & 'wake up' \\
\hline ka-tavəð-ó & ka-dat-tavəð-ó & ka-dát-tavəð-a & 'spit' \\
\hline ka-kw ${ }^{\mathrm{w}}$ əreðó & ka-gak-k ${ }^{\mathrm{w}}$ əreð-ó & ka-gák-kw əreð-a & 'scratch' \\
\hline ka-vəleð-ó & ka-vaf-fəleð-ó & ka-váf-fəleð-a & 'pull' \\
\hline
\end{tabular}

When the perfective suffix combines with the durative/iterative prefix, the perfective suffix remains high-toned, and the reduplicant is low-toned:

Again, only one $\mathrm{H}$ tone emerges. At this point, there is no clear motivation for why it is the perfective $\mathrm{H}$ and not the iterative $\mathrm{H}$ that is retained. We return to this question in Sect. 5.3.

A final combination, with the perfective final vowel and a preverbal object marker,

\begin{tabular}{|c|c|c|}
\hline & Perfective objects & Imperfective objects \\
\hline 3SG (non-human) & k-a-vəleð-ó & k-a-vóléð-a \\
\hline $1 \mathrm{SG}$ & k-a-vəleð-í-jé & k-a-nว́-vəleð-a \\
\hline $2 \mathrm{SG}$ & k-a-vəleð-á-yá & k-a-yá-vəleð-a \\
\hline 3SG (human) & k-a-vəleð-ó-yó & k-a-yó-vəleð-a \\
\hline 1DUAL INCL & k-a-vəleð-ə́-ńda & k-á-ńdə-vəleð-a \\
\hline 1PL EXCl & k-a-vəleð-álánda & k-a-jə́-vəleð-álánda \\
\hline 1PL INCL & k-a-vəleð-ว́-ńdŕ & k-á-ńdə-vəleð-a-ŕ \\
\hline 2PL & k-a-vəleð-ว́-ńda & k-á-ńdə-vəleð-a \\
\hline 3PL & k-a-vəleð-ว́-lo & k-a-vóléð-a-lo \\
\hline
\end{tabular}
is impossible, because in the perfective the object marker follows the perfective final vowel. Imperfective verbs with preverbal object markers are given for comparison:

Unlike object prefixes, object suffixes do not interact with the $\mathrm{H}$ on the perfective suffix - both may bear high tone. As such, the H tones on these suffixes do not compete in the relevant sense. Note that the presence of the object suffix reduces the final 
vowel /ó/ to [ə́], which is colored by the following vowel in the first two forms, raising before [n] (1SG), lowering before [a] (2SG), rounding before [o] (3SG human), and deleting before other vowels (1DUAL INCL). ${ }^{25}$

The tone patterns introduced so far are reminiscent of Meeussen's Rule in Bantu languages, in which the second of two juxtaposed $\mathrm{H}$ tones deletes (Goldsmith 1984). The reverse, in which the first of two high tones deletes, is sometimes labeled Anti-Meeussen's Rule, and has been documented in languages such as Haya (Hyman 1993), Kikerewe (Odden 1998a, 2000), and Rimi (Goldsmith 1984; Myers 1997; Schadeberg 1978, 1979). While some researchers avoid using the label 'Meeussen's Rule' to identify right-to-left deletion, ${ }^{26}$ the difference is only directional. Both deletion rules can be analyzed as responses to the OCP (Myers 1991, 1997), the ban on adjacent $H$ tones. In Moro, we have seen that both patterns are found, with $\mathrm{H}$ tone preserved on the object prefix and deleted on the reduplicative prefix (second tone deletes) or preserved on the perfective suffix, but deleted on the reduplicative prefix (first tone deletes). Adjacency is not a requirement in Moro, as the perfective suffix prevents the reduplicative prefix from bearing tone, despite the intervening root.

\subsection{Domain of high tone competition}

Tone competition in Moro only occurs within a domain we label the macrostem, a term used for a similar constituent in Bantu languages that includes object prefixes, verb roots and extension suffixes, but excludes subject agreement prefixes and other types of inflectional prefixes (Bickmore 2000; Downing 2003; Hyman and Ngunga 1994; Myers 1987, 1997; and others). The macrostem is important as the locus of phonological processes such as tone interactions or vowel harmony. In Moro, the leftmost morpheme in the macrostem is the preverbal object marker (OM) and the rightmost is the final aspect/mood vowel. The D-stem is within the macrostem, and includes the root, extension suffixes, durative/iterative reduplicant, and the $/ \mathrm{v}-/$ prefix.

Morphological schema for verbs

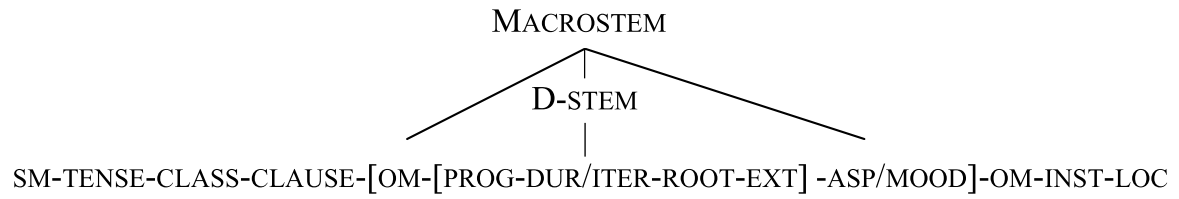

We have already shown how the high-toned perfective suffix can combine with following high-toned object suffixes with no tone interaction (51). We attribute this to the perfective object markers being positioned outside the macrostem, thus freeing it from the single-H constraint.

\footnotetext{
${ }^{25}$ The reduction of /o/ to schwa is independently attested in nouns, where it is widespread (Gibbard et al. 2009), and this same reduction occurs when object clitics are added to high-toned imperative verb stems that end in [ó]: [kóréðó] 'scratch!' vs. [kóréðá-yó] 'scratch him!'

${ }^{26}$ For example, Odden (1998a) uses the term 'deletion of H' rather than 'Meeussen's Rule' to describe deletion of a preceding $\mathrm{H}$, saving the latter for its typical left-to-right designation.
} 
The same non-interaction is also true of $\mathrm{H}$ tones in the prefixes preceding the macrostem in (52). Subject agreement prefixes that bear H tone, such as 2PL / já-/, cooccur with $\mathrm{H}$ on the macrostem, either the root tone of the imperfective, or the perfective suffix tone. Note that the $3 \mathrm{SG}$ prefix is the $g / l$ noun class concord marker from (4), and that it also occurs following the 2PL subject agreement prefix:

\begin{tabular}{|c|c|c|c|c|}
\hline & 3SG impv & 2PL: /ná-/ impv & 2PL: /já-/ pfv & \\
\hline a. & k-a-ðว́w-á & pá-g-a-ðáw-á & já-g-a-ðəw-ó & 'poke' \\
\hline b. & k-a-vóléð-a & já-g-a-vóléð-a & já-g-a-vəleð-ó & 'pull' \\
\hline c. & k-áff-a & ná-g-áff-a & ná-g-aff-ó & 'shoot' \\
\hline
\end{tabular}

Deletion does not occur even in the case of vowel initial roots, where hiatus resolution renders the two surface $\mathrm{H}$ tones adjacent.

Another pre-macrostem $\mathrm{H}$ that does not interact with macrostem $\mathrm{H}$ occurs in the past tense, marked by /Cá-/, with reduplication of the noun class agreement marker (shown below with $3 \mathrm{SG}$ noun class marker $/ \mathrm{y}-/$, cf. (4)). It, too, is located outside the macrostem, and its $\mathrm{H}$ tone co-occurs with both $\mathrm{H}$ tone on subject agreement to its left and with $\mathrm{H}$ tone on the macrostem to its right:

(54) Non-competition of multiple pre-macrostem prefixes

3SG: /y-/ impv 3sG: /g-/ past impv 1SG: /é-/ impv 1SG: /é-/ past impv

$\begin{array}{lllll}\text { a. y-a-ðáw-á } & \text { yá-y-a-ðáw-á } & \text { é-g-a-ðáw-á } & \text { é-gá-g-a-ðáw-á } & \text { 'poke’ } \\ \text { b. y-a-vóléð-a } & \text { yá-y-a-vóléð-a } & \text { é-g-a-vóléð-a } & \text { é-gá-g-a-vóléð-a } & \text { 'pull’ } \\ \text { c. y-áff-a } & \text { yá-y-áff-a } & \text { é-g-áff-a } & \text { é-gá-g-áff-a } & \text { 'shoot' }\end{array}$

The lack of tone interaction outside the macrostem can result in as many as three $\mathrm{H}$ tones on adjacent syllables, as seen in (54c) é-gá-g-áff-a 'I was going to shoot.' Although the forms in (54) are shown with imperfective aspect, the same pattern occurs with perfective: ex. é-gá-g-aff-ó 'I had shot'. From these examples, it is clear that the restriction of only one autosegmental $\mathrm{H}$ tone, spread or not, only applies within the domain of the macrostem. Elsewhere, it is acceptable to have sequences of $\mathrm{H}$ tone originating on different morphemes.

\subsection{Analysis of tone competition}

While the three instances of tone competition from Sect. 4.1 appear to be uniform, there is an important difference between the reduplicated durative/iterative prefix and the two other affixes. While the durative/iterative prefix occurs inside the D-stem, the preverbal object marker and perfective suffix are both D-stem external. This can be shown most clearly by the behavior of the /v-/ prefix, which was observed to occur before vowel-initial roots in Sect. 4.2, and precedes the reduplicant if present:
Imperfective
Durative/Iterative imperfective
a. $\mathrm{k} \Lambda$-v-índ-iə $\mathrm{k} \Lambda$-v- $\mathrm{k} k \mathrm{k}-\Lambda \mathrm{nd}-\mathrm{i} \partial$

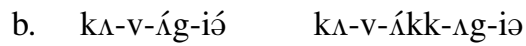
c. ka-v-ágə́ðat-a ka-v-ákk-agəðat-a
'hold'
'put'
'go around in circles' 
The same ranking from Sect. 4 that generated high tone in heavy syllables at the left edge of verb roots in (34) predicts that $\mathrm{H}$ will occur exclusively on the durative/iterative prefix, as it is at the left edge of the D-stem and a heavy syllable. As before, brackets mark the boundary of the D-stem on the input form:

(56) H competition with durative/iterative prefix

\begin{tabular}{|c||c|c|c|c|}
\hline /ka-[ðað-ðəw]-a/ & $\mathrm{CE}(\mathrm{H}, \mathrm{FT})$ & STEM-H & $\mathrm{AL}(\mathrm{H}, \mathrm{L})$ & $\mathrm{AL}(\mathrm{H}, \mathrm{R})$ \\
\hline a. ka-(ðað)(ðəwa) & & $* !$ & & \\
\hline b. ka-(ðáð)(ðə́wá) & $* !$ & & & \\
\hline c. ka-(ðáð)(ðəwa) & & & & $* *$ \\
\hline d. ka-(ðað)(ðə́wá) & & & $* !$ & \\
\hline
\end{tabular}

Resorting to the deletion of $\mathrm{H}$ on the root in the presence of the durative/iterative prefix is not necessary. This is because the tone that appears on the durative/iterative prefix is the same default tone that we observed on the root, both of which are due to STEM-H.

The preverbal object marker and perfective suffix present a different situation. They are external to the macrostem, and are underlyingly associated with H. Yet we can account for them simply by combining constraints used in the last two sections. We begin with the simpler case of the perfective suffix /-ó/ $(48,50)$. Here, the position of the $\mathrm{H}$ is notable because it is rightmost within the verb. We can account for the $\mathrm{H}$ on this suffix with the constraints from Sect. 4 combined with two other constraints which were introduced in Sect. 3 to analyze the distribution of $\mathrm{H}$ with nouns. First, the unbounded version of OCP-H, which constrained the lexical tone melodies on nouns (18), is responsible for the emergence of only a single $\mathrm{H}$ in the macrostem. Second, the faithfulness constraint IDENT-IO(H), which required faithfulness to underlying representations in nouns (13), favors preservation of affix tone to the default root tone.

In the perfective, $\mathrm{H}$ on the suffix is favored over the $\mathrm{H}$ on the $\mathrm{D}$-stem despite the violation of STEM-H. Curly brackets mark the edges of the macrostem in the input. We only consider candidates with default $\mathrm{H}$ on the D-stem that satisfy the ranking established in Sect. 4:

$H$ competition with perfective suffix: OCP-H, IDENT-IO(H) $\gg$ STEM-H

\begin{tabular}{|c||c|c|c|}
\hline$/$ ka- $\{[$ ðað-ðəw]-ó\}/ & OCP-H & Ident-IO(H) & Stem-H \\
\hline a. ka-ðáð-ðəw-ó & $* !$ & & \\
\hline b. ka-ðáð-ðəw-o & & $* !$ & \\
\hline$\sigma \quad$ c. ka-ðað-ðəw-ó & & & $*$ \\
\hline
\end{tabular}

Note that although we do not give autosegmental representations, violations of OCP are only marked for separate $\mathrm{H}$ tones, not multiple linkings of a single $\mathrm{H}$, per the definition in (18). As (57) shows clearly, $\mathrm{H}$ emerges on the perfective suffix due to the faithfulness constraint, as the perfective is $\mathrm{H}$ underlyingly. This applies even in forms with durative/iterative prefix as the tone there is assigned by the STEM-H constraint, as we showed in (56). 
We now turn to the final cases of tone competition involving preverbal object markers. Like the perfective suffix, $\mathrm{H}$ is underlyingly associated with the object marker. Evidence for this position comes from the fact that the same object markers also bear $\mathrm{H}$ in the perfective when they follow the verb (51). Additionally, there is evidence that $\mathrm{H}$ on the object marker is external to the D-stem, meaning that it could not be assumed to follow from the same default $\mathrm{H}$ assignment that produced $\mathrm{H}$ on roots and on the durative/iterative prefix:

(58) H competition with preverbal object marker: $\mathrm{OCP}-\mathrm{H}$, IDENT-IO(H) $\gg \mathrm{STEM}-\mathrm{H}$

\begin{tabular}{|c||c|c|c|}
\hline /ka- $\{$ né-[ðəw]-a $\} /$ & OCP-H & Ident-IO(H) & Stem-H \\
\hline a. ka-jó-ðə́w-á & $* !$ & $* !$ & \\
\hline b. ka-jə-ðáw-á & & & $*$ \\
\hline c. ka-jó-ðəw-a & & & \\
\hline
\end{tabular}

Like with perfective suffixes, faithfulness to underlying $H$ tones and a constraint on multiple $\mathrm{H}$ tones within the macrostem conspire to restrict $\mathrm{H}$ to the preverbal object marker. The same result is produced when durative/iterative reduplication occurs with preverbal object markers:

(59) H competition with preverbal object marker + durative/iterative reduplication

\begin{tabular}{|c||c|c|c|}
\hline$/$ ka-\{né-[ðаð-ðəw]-a $\} /$ & OCP-H & Ident-IO(H) & Stem-H \\
\hline \hline a. ka-nə́-ðáð-ðəw-a & $* !$ & $* !$ & \\
\hline b. ka-лə-ðáð-ðəw-a & & & \\
\hline c. ka-jó-ðað-ðəw-a & & & $*$ \\
\hline
\end{tabular}

Thus, tone competition is always resolved in favor of underlying $\mathrm{H}$ tone, regardless of its direction with respect to the root. We have not found any instances of multiple underlyingly linked $\mathrm{H}$ tones occurring within the macrostem, we will not work out the predictions our analysis might make if such a situation arose.

Another unresolved issue is the lack of tone doubling with preverbal object markers. We attribute this to the foot aligned with the left edge of the D-stem. CE(H,FT) would be violated if spreading into the $\mathrm{D}$-stem were to occur. This provides an argument that $\mathrm{CE}(\mathrm{H}, \mathrm{FT})$ and $\mathrm{AL}(\mathrm{FT}, \mathrm{L})$ are ranked above STEM-H:

(60) Ranking for non-spreading from preverbal OM: $\mathrm{CE}(\mathrm{H}, \mathrm{FT}), \mathrm{AL}(\mathrm{FT}, \mathrm{L}) \gg$ STEM-H

\begin{tabular}{|c||c|c|c|c|c|}
\hline /ka-\{né-[ðəw]-a\}/ & OCP-H & Ident-IO(H) & CE(H,Ft) & AL(FT,L) & STEM-H \\
\hline \hline b. kanó(ðáwá) & & & $* !$ & & \\
\hline c. ka(nóðá)wa & & & & $* !$ & \\
\hline d. kajó(ðəwa) & & & & & $*$ \\
\hline
\end{tabular}

Thus, the ingredients for the lack of spreading from preverbal object markers are contained in the analysis of Sect. 4 , minus a single ranking. 
Finally, we turn to the behavior of object prefix tone with vowel-initial D-stems. As mentioned in Sect. 4.2, the tone of the object prefix appears on the preceding non-macrostem prefix instead of within the D-stem:

(61) Preverbal object markers with vowel-initial roots
a. /k-a-\{né-[abatf]-a $\} /$
[kánabatfa]
's/he is about to lift me'
b. /k- $\Lambda-\{\mathbf{y} \hat{\Lambda}-[\Lambda$ wut $]-\Lambda\} /$
$[\mathrm{k} \hat{\mathbf{g}} \Lambda$ wut- $\Lambda$ ]
's/he is about to drop you'
c. /k-a- $\{$ né-[akk-aləf-ət]]-iə\}\}/
[kíjıkkıləfətiə]
's/he keeps promising me'

It appears as if the constraint $*[\mathrm{~V}]_{\sigma}-\mathrm{H}(39)$ might be responsible for preventing $\mathrm{H}$ tone on the vowel-initial root. But this cannot be the case, as this would incorrectly predict $\mathrm{H}$ on a heavy syllable (cf. (61c)).

The problem appears to be that the D-stem cannot host tone that 'belongs' to a morpheme outside it. The constraint Morpheme DePEndency (M-DEP) (McCarthy 2000; Lubowicz 2010) prevents segments from having different morphological affiliations in the input and output. This can be straightforwardly applied to tone, with D-stem as the morphological domain:

\section{MORPHEME DEPENDENCY (M-DEP)}

Only a $\mathrm{H}$ whose input correspondent belongs to the D-stem belongs to the D-stem in the output.

This constraint is vacuously satisfied with $\mathrm{H}$ tone epenthesis, the normal situation of $\mathrm{H}$ tones arising in the D-stem (Lubowicz 2010), but it prevents $\mathrm{H}$ tone from emerging in the D-stem if it did not originate there.

Applied to the $\mathrm{H}$ associated with preverbal object markers, M-DEP forces it to appear outside the D-stem. Below, we only show candidates in which the second vowel is maintained and the first dropped, the general pattern in Moro regardless of morpheme boundaries.

Preverbal object markers and V-initial roots: IDENT-IO(H), M-DEP 》STEM-H

\begin{tabular}{|c||c|c|c|}
\hline$/$ k-a- $\{$ né-[abatf]-a\}/ & Ident-IO(H) & M-DEP & STEM-H \\
\hline \hline a. kanabatfa & $* !$ & & $*$ \\
\hline b. kanábatfa & & $* !$ & \\
\hline c. kanabátfa & & $* !$ & \\
\hline$\sigma \quad$ d. kánabatfa & & & $*$ \\
\hline
\end{tabular}

Deletion of the $\mathrm{H}$ associated with the object marker is blocked by IDENT-IO(H) in (63a), and the $\mathrm{H}$ cannot appear within the D-stem due to M-DEP. M-DEP could also account for the lack of spreading from the preverbal object markers onto the stem. It is not clear whether an explanation with M-DEP or the explanation using CRISPEDGE in (60) is the correct one; either constraint produces the same result.

This concludes the discussion of tone distribution in the Moro macrostem. We have shown that only one $\mathrm{H}$ tone may surface per macrostem, and if there are macrostem affixes, tone appears on those affixes and does not spread. The analysis of 
these facts was accomplished with a basic OCP constraint combined with faithfulness constraints.

Below, we summarize the constraint rankings from Sects. 3, 4, and 5, noting that in many cases, the tone patterns characteristic of verbal or nominal tone have provided different ranking arguments for many of the same constraints on $\mathrm{H}$. In the Appendix we provide a list of these ranking arguments with references to the tableau illustrating each of them. In some cases, direct arguments were provided over the course of the paper for constraint rankings that were eventually entailed by the transitivity of other constraint rankings. These are omitted for simplicity. Bidirectional arrows represent cophonologies, where both rankings are represented by different lexical classes.

(64) Summary of constraint ranking

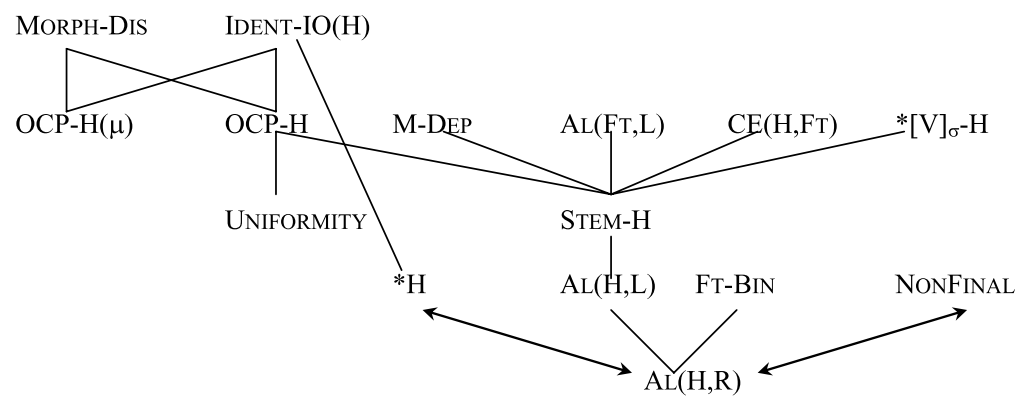

The rankings of nouns and verbs never contradict each other, except in the cases of cophonologies. Also, it is interesting to observe that cophonologies, where they arose, involved the reranking of relatively low-ranked constraints.

\section{Conclusion}

In this paper, we presented a description and analysis of tone on nouns and verbs in the Thetogovela dialect of Moro. Nouns were shown to contrast words with $\mathrm{H}$ tone and those without, but were also split into at least two lexical classes depending on whether high tone spread or did not spread to the right edge. We modeled this effect with cophonologies. We also showed how assumptions about input $\mathrm{H}$ tones can be successfully analyzed in an OT framework by considering a variety of input $\mathrm{H}$ configurations. In addition, nouns were subject to an OCP restriction favoring a single $\mathrm{H}$ within the word. Tone spreading and OCP restrictions on spreading were also attested with nominal affixes.

The distribution of $\mathrm{H}$ tone on Moro verbs shows several similarities to the distribution of $\mathrm{H}$ tone on nouns: in both cases, $\mathrm{H}$ spreads to the right, and there are lexical classes defined in terms of whether tone spreads or does not. Furthermore, the verbal macrostem was subject to a global OCP constraint on $\mathrm{H}$, like noun stems. However, while $\mathrm{H}$ spreading in nouns was unbounded, verbs exhibit tone doubling. The Moro data provides clear arguments that tone doubling, at least in this language, should be analyzed with reference to binary prosodic feet. The construction of these feet is 
weight sensitive, showing a three-way distinction of syllable size, with $\mathrm{H}$ avoiding onsetless light syllables, overt tone doubling in CV light syllables, and a single $\mathrm{H}$ tone appearing on heavy syllables. Moreover, we show that it is unnecessary to assume underlying lexical distinctions between verb roots for tone, as surface distribution of $\mathrm{H}$ tone is determined by constraints. Unlike nouns, lexical distinctions between verb roots concern only whether $\mathrm{H}$ tone spreads or does not spread. In addition, we presented tone-based arguments for two morphological constituents, the derived stem and the macrostem, similar to those found in related Bantu languages. Unlike nouns, verbal derived stems always host a $\mathrm{H}$ tone except under special circumstances, and the OCP applies within the macrostem, with affixes preserving underlyingly linked tone. Theoretically, our analysis is one of the few analyses of tone articulated within OT that demonstrates how output surface constraints can effectively regulate tone distribution without explicit assumptions about input tone and specific tone positions.

This study of Moro contributes not only to the description of Kordofanian languages, which are poorly documented, but also enriches our typological knowledge of the tone systems of the world's languages. In particular, the distribution of privative $\mathrm{H}$ in Moro, while showing canonical properties of African tonal languages, bearing striking resemblance to Bantu languages in particular, also shares properties with what Hyman (2006) terms stress accent languages. This is particularly true for Moro verbs. First, high tone only shows obligatoriness within the D-stem. Second, within verbs high tone is aligned with a particular edge of a morphological domain, again the D-stem, rather than being underlyingly associated with certain syllables. Edge alignment is also a property of stress systems. Furthermore, syllable weight and foot structure, constructs which usually constrain stress, both play crucial roles in the distribution of $\mathrm{H}$ only in verbs in Moro. Thus, the noun-verb asymmetry in Moro shows a general tendency for high tone nouns to be more 'tone-like' and high tone in verbs to be more 'stress-like'. We leave for future research the question of what is to be made of this observation, and how it might be explained by more general typological or theoretical concepts.

Open Access This article is distributed under the terms of the Creative Commons Attribution Noncommercial License which permits any noncommercial use, distribution, and reproduction in any medium, provided the original author(s) and source are credited.

\section{Appendix: Constraint ranking arguments}

Below is the complete list of constraint rankings which we have argued for in this paper and their appropriate reference. Note that in some cases, combinations of rankings entail others.

(A1) Ranking producing spreading in nouns: $\mathrm{AL}(\mathrm{H}, \mathrm{R}) \gg * \mathrm{H}$

(A2) Ranking preventing shifting in nouns: $\mathrm{IDENT}-\mathrm{IO}(\mathrm{H}) \gg{ }^{*} \mathrm{H}$

(A3) Ranking for nouns without spreading: $* \mathrm{H} \gg \mathrm{AL}(\mathrm{H}, \mathrm{R})$

(A4) Ranking resolving inputs with multiple $H$ : OCP-H, IDENT-IO(H) $\gg$ UNIFORMITY

(A5) Restricted spreading from /é-/ prefix: MORPH-DIS, IDENT-IO(H) $\gg \mathrm{OCP}-\mathrm{H}(\mu), \mathrm{OCP}-\mathrm{H}$ 
(A6) Ranking accounting for tone doubling: STEM-H, AL(H,L), CE(H,FT) $\gg \mathrm{AL}(\mathrm{H}, \mathrm{R})$

(A7) Short $H-H$, tone doubling to final vowel: $\mathrm{AL}(\mathrm{H}, \mathrm{R}) \gg$ NONFINAL

(A8) Short $H$-L, no tone doubling to final vowel: NONFINAL $\gg \operatorname{AL}(H, R)$

(A9) Heavy syllable verb roots: $\mathrm{AL}(\mathrm{H}, \mathrm{L}) \gg \mathrm{AL}(\mathrm{H}, \mathrm{R})$

(A10) Long V-initial verb roots: $*[\mathrm{~V}]_{\sigma}-\mathrm{H} \gg \mathrm{AL}(\mathrm{H}, \mathrm{L})$

(A11) Short V-initial verb roots: $*[\mathrm{~V}]_{\sigma}-\mathrm{H} \gg \mathrm{STEM}-\mathrm{H}$

(A12) Short $V$-initial verb roots with extension suffix: STEM-H $\gg \mathrm{AL}(\mathrm{H}, \mathrm{L})$

(A13) H competition with perfective suffix: OCP-H, IDENT-IO(H) 》STEM-H (57)

(A14) H competition with preverbal object marker: OCP-H, IDENT-IO(H) $\gg \mathrm{STEM}-\mathrm{H}$

(A15) Ranking for non-spreading from preverbal OM: $\mathrm{CE}(\mathrm{H}, \mathrm{FT}), \mathrm{AL}(\mathrm{FT}, \mathrm{L})$ $\gg$ STEM-H

(A16) Preverbal object markers and V-initial roots: IDENT-IO(H), M-DEP $\gg$ STEM-H

\section{References}

Alderete, John D., and Stefan A. Frisch. 2007. Dissimilation in grammar and the lexicon. In The Cambridge handbook of phonology, ed. Paul de Lacy, 379-398. Cambridge: Cambridge University Press.

Anttila, Arto. 2002. Morphologically conditioned phonological alternations. Natural Language \& Linguistic Theory 20: 1-42.

Anttila, Arto. 2009. Derived environment effects in colloquial Helsinki Finnish. In The nature of the word: Essays in honor of Paul Kiparsky, eds. Kristin Hanson and Sharon Inkelas, 433-460. Cambridge: MIT Press.

Anttila, Arto, and Adams Bodomo. 2007. OCP effects in Dagaare. Paper presented at the $81^{\text {st }}$ annual meeting of the Linguistic Society of America, Anaheim, CA.

Bickmore, Lee. 1989. Tone in Kinyambo. In Vol. 6 of Current approaches to African linguistics, eds. Laurice Tuller and Isabelle Häik, 19-26. New York: Mouton de Gruyter.

Bickmore, Lee. 1999. High tone spread in Ekegusii revisited: An optimality theoretic account. Lingua 109: $109-153$.

Bickmore, Lee. 2000. Downstep and fusion in Namwanga. Phonology 17: 297-331.

Bickmore, Lee. 2003. The use of feet to account for binary tone spreading. In Frankfurter Afrikanistische Blatter 15, ed. Ross-Juliet Anyanwu. Köln: Rudiger Koeppe Verlag.

Bradshaw, Mary. 1998. Tone alternations in the associative construction of Suma. In Language history and linguistic description in Africa, eds. Thomas J. Hinnebusch and Ian Maddieson, 117-125. Trenton: Africa World Press.

Cassimjee, Farida, and Charles Kisseberth. 1998. Optimal domains theory and Bantu tonology: A case study from Isixhosa and Shingazidja. In Theoretical aspects of Bantu tone, eds. Larry Hyman and Charles Kisseberth, 33-132. Stanford: CSLI.

de Lacy, Paul. 2001. Markedness in prominent positions. In MIT working papers in linguistics 40, eds. Ora Matushansky, Albert Costa, Javier Martin-Gonzalez, Nathan Lance, and Adam Szczegielniak, 53-66. Cambridge: MITWPL.

Downing, Laura. 2000. Morphological and prosodic constraints on Kinande verbal reduplication. Phonology 17: 1-38.

Downing, Laura. 2003. Stress, tone, and focus in Chichewa and Xhosa. In Stress and tone-the African experience, ed. Ross-Juliet Anyanwu, Vol. 15 of Frankfurter Afrikanistische Blätter. Köln: Rüdiger Köppe Verlag.

Duanmu, San. 1992. An autosegmental analysis of tone in four Tibetan languages. Linguistics of the TibetoBurman Area 15: 65-91.

Duanmu, San. 1993. Rime length, stress, and association domains. Journal of East Asian Linguistics 2: 1-44. 
Fukazawa, Haruka. 1999. Theoretical implications of OCP effects on features in optimality theory. PhD dissertation, University of Maryland, College Park.

Gibbard, George, Hannah Rohde, and Sharon Rose. 2009. Moro noun class morphology. In Selected proceedings of the 38th annual conference on African linguistics, eds. Masangu Matondo, Fiona McLaughlin, and Eric Potsdam, 106-117. Somerville: Cascadilla Proceedings Project.

Goedemans, Rob. 1998. Weightless segments. The Hague: Holland Academic Graphics.

Goldsmith, John. 1976. Autosegmental phonology. PhD dissertation, Massachusetts Institute of Technology.

Goldsmith, John. 1984. Meeussen's rule. In Language sound and structure, eds. Mark Aronoff, Richard Oehrle, Frances Kelley, and Bonnie Stephens, 245-259. Cambridge: MIT.

Goldsmith, John. 1987. Tone and accent, and getting the two together. BLS 14: 88-104.

Gordon, Matthew. 2005. A perceptually-driven account of onset-sensitive stress. Natural Language \& Linguistic Theory 23: 595-653.

Hansson, Gunnar Ólafur. 2004. Tone and voicing agreement in Yabem. In Proceedings of the 23rd west coast conference on formal linguistics, eds. Vineeta Chand, Ann Kelleher, Angelo J. Rodríguez, and Benjamin Schmeiser, 318-331. Somerville: Cascadilla.

Heny, Frank. 1971. Explanatory tone assignment rules in Bantu. In Papers in African linguistics: Current inquiry into language and linguistics I, eds. Chin-Wu Kim and Herbert Stahlke, 175-199. Edmonton: Linguistics Research, Inc.

Hyman, Larry M. 1978. Tone and/or accent. In Elements of tone, stress, and intonation, ed. Donna Jo Napoli. Washington: Georgetown University Press.

Hyman, Larry M. 1982. Globality and the accentual analysis of Luganda tone. Journal of Linguistic Research 4: 1-40.

Hyman, Larry M. 1993. Problems for rule ordering in phonology: Two Bantu test cases. In The last phonological rule, ed. John Goldsmith, 195-222. Chicago: University of Chicago Press.

Hyman, Larry M. 2001. Privative tone in Bantu. In Cross-linguistic studies of tonal phenomena, ed. Shigeki Kaji, 237-257. Tokyo: Institute for the Study of Languages and Cultures.

Hyman, Larry M. 2006. Word-prosodic typology. Phonology 23: 225-257.

Hyman, Larry M., and Ernest Byarushengo. 1984. A model of Haya tonology. In Autosegmental studies in Bantu tone, eds. George N. Clements and John Goldsmith, 55-103. Dordrecht: Foris.

Hyman, Larry M., and Armindo Ngunga. 1994. On the non-universality of tonal association 'conventions': Evidence from Ciyao. Phonology 11: 25-68.

Inkelas, Sharon. 1999. Exceptional stress-attracting suffixes in Turkish: Representations vs. the grammar. In The prosody-morphology interface, eds. René Kager, Harry van der Hulst, and Wim Zonneveld, 134-187. Cambridge: Cambridge University Press.

Inkelas, Sharon, and Cheryl Zoll. 2007. Is grammar dependence real? Linguistics 45: 133-171.

Itô, Junko, and Armin Mester. 1994. Reflections on CodaCond and alignment. In Phonology at Santa Cruz 3, eds. Jason Merchant, Jaye Padgett, and Rachel Walker, 27-46. Santa Cruz: Linguistics Research Center.

Itô, Junko, and Armin Mester. 1999. Realignment. In The prosody-morphology interface, eds. René Kager, Harry van der Hulst, and Wim Zonneveld, 188-217. Cambridge: Cambridge University Press.

Kawahara, Shigeto. 2008. On the proper treatment of non-crisp-edges. In Japanese/Korean linguistics 13, eds. Hudson Mutsuko Endo, Peter Sells, and Sun-Ah Jun, 55-67. Stanford: CSLI Publications.

Kawu, Ahmadu. 2000. Structural markedness and non-reduplicative copying. In Proceedings of NELS 20, eds. Juli A. Carter, Rose-Marie Dechaine, William Philip, and Tim D. Sherer, 377-388. Amherst: GLSA.

Kisseberth, Charles, and David Odden. 2003. Tone. In The Bantu languages, eds. Derek Nurse and Gérard Philippson, 59-70. London: Routledge.

Kisseberth, Charles, and Emmanuel Ndabarasa. 1993. Ruciga nominal tonology. Paper presented at the annual conference on African linguistics, The Ohio State University.

Leben, William. 1973. Suprasegmental phonology. PhD dissertation, Massachusetts Institute of Technology. Distributed by Indiana University Linguistics Club.

Leben, William. 2003. Tonal feet as tonal domains. In Trends in African linguistics 5: Linguistic typology and representation of African languages, ed. John Mugane, 129-138. Trenton: Africa World Press.

Lubowicz, Ania. 2010. Infixation as morpheme absorption. In Phonological argumentation: Essays on evidence and motivation, ed. Steven Parker. London: Equinox.

McCarthy, John. 2000. Faithfulness and prosodic circumscription. In Optimality theory: Syntax, phonology, and acquisition, eds. Joost Dekkers, Frank van der Leeuw, and Jeroen van de Weijer, 151-189. Oxford: Oxford University Press. 
McCarthy, John, and Alan Prince. 1995. Faithfulness and reduplicative identity. In University of Massachusetts occasional papers in linguistics 18: Papers in optimality theory, eds. Jill Beckman, Suzanne Urbanczyk, and Laura Walsh Dickey, 249-384. Amherst: GLSA.

McCawley, John. 1970. Some tonal systems that come close to being pitch accent systems but don't quite make it. CLS 6: 526-532.

Mmusi, Sheila Onkaetse. 1992. OCP violations in Setswana: Evidence for redefining the OCP? Studies in the Linguistic Sciences 22: 123-142.

Mutaka, Ngessimo. 1994. The lexical tonology of Kinande. Munich: LINCOM Europa.

Mutaka, Ngessimo, and Larry M. Hyman. 1990. Syllables and morpheme integrity in Kinande reduplication. Phonology 7: 73-119.

Mwita, Leonard Chacha. 2008. Verbal tone in Kuria. PhD dissertation, University of California, Los Angeles.

Myers, Scott. 1987. Tone and the structure of words in Shona. PhD dissertation, University of Massachusetts, Amherst.

Myers, Scott. 1991. Persistent rules. Linguistic Inquiry 22: 315-344.

Myers, Scott. 1997. OCP effects in optimality theory. Natural Language \& Linguistic Theory 15: 847-892.

Ngunga, Armindo. 2000. Phonology and morphology of the Ciyao verb. Stanford monographs in African language. Stanford: Center for the Study of Language and Information.

Odden, David. 1980. Associative tone in Shona. Journal of Linguistic Research 1: 37-51.

Odden, David. 1986. On the role of the obligatory contour principle in phonological theory. Language 62: 353-383.

Odden, David. 1989. Predictable tone systems in Bantu. In Autosegmental studies on pitch accent systems, eds. Harry van der Hulst and Norval Smith, 225-251. Dordrecht: Foris.

Odden, David. 1994. Adjacency parameters in phonology. Language 70: 289-330.

Odden, David. 1995. The status of onsetless syllables in Kikerewe. OSU Working Papers in Linguistics 47: 89-110.

Odden, David. 1998a. Verbal tone melodies in Kikerewe. In Language history and linguistic description in Africa, eds. Thomas J. Hinnebusch and Ian Maddieson, 177-184. Trenton: Africa World Press.

Odden, David. 1998b. Principles of tone assignment in Tanzanian Yao. In Theoretical aspects of Bantu tone, eds. Larry Hyman and Charles Kisseberth, 265-314. Stanford: CSLI.

Odden, David. 2000. Opacity and ordering: H-deletion in Kikerewe. Linguistic Review 17: 323-335.

Odden, David. 2006. Minimality and onsetless syllables in Zinza. Phonology 23: 431-441.

Orgun, Orhan. 1996. Correspondence and identity constraints in two-level optimality theory. In Proceedings of the 14th west coast conference on formal linguistics, eds. Jose Camacho, Lina Choueiri, and Maki Watanabe 399-413. Stanford: CSLI.

Orie, Olanike. 2000. Syllable asymmetries in comparative Yoruba phonology. Journal of Linguistics 36: 39-84.

Pater, Joe. 2007. The locus of exceptionality: Morpheme-specific phonology as constraint indexation. In University of Massachusetts occasional papers in linguistics 32: Papers in optimality theory III, eds. Leah Bateman, Michael O’Keefe, Ehren Reilly, and Adam Werle, 259-296. Amherst: GLSA, University of Massachusetts.

Pater, Joe. 2009. Morpheme-specific phonology: Constraint indexation and inconsistency resolution. In Phonological argumentation: Essays on evidence and motivation, ed. Steve Parker, Advances in optimality theory, 123-154. London: Equinox.

Pearce, Mary. 2006. The interaction between metrical structure and tone in Kera. Phonology 23.2: 259286.

Prince, Alan, and Paul Smolensky. 1993. Optimality theory: Constraint interaction in generative grammar. Rutgers University Center for Cognitive Science Technical Report 2.

Savà, Graziano. 2005. A grammar of Ts'amakko. Cologne: Rüdiger Köppe Verlag.

Schadeberg, Thilo. 1978. Über die Töne der nominalen und pronominale Formen im Rimi. Afrika und Übersee 56: 189-209.

Schadeberg, Thilo. 1979. Über die Töne der verbalen Formen im Rimi. Afrika und Übersee 57: $288-313$.

Schadeberg, Thilo. 1981. A survey of Kordofanian. Volume 1: The Heiban group. Hamburg: Helmut Buske.

Struijke, Caro. 2002. Existential faithfulness: A study of reduplicative TETU, feature movement, and dissimilation. New York: Routledge.

Suzuki, Keiichiro. 1998. A typological investigation of dissimilation. PhD dissertation, University of Arizona, Sierra Vista, AZ. 
Topintzi, Nina. 2003. Issues of locality and morphologically induced non-identity in the N. Karanga assertive and non-assertive patterns. In University College London working papers in linguistics 15, eds. Ad Neeleman and Reiko Vermeulen, 327-354.

Weidman, Scott, and Sharon Rose. 2006. A foot-based reanalysis of edge-in tonal phenomena in Bambara. In Proceedings of the $25^{\text {th }}$ west coast conference on formal linguistics, eds. Donald Baumer, David Montero, and Michael Scanlon, 426-343. Somerville: Cascadilla Press. 